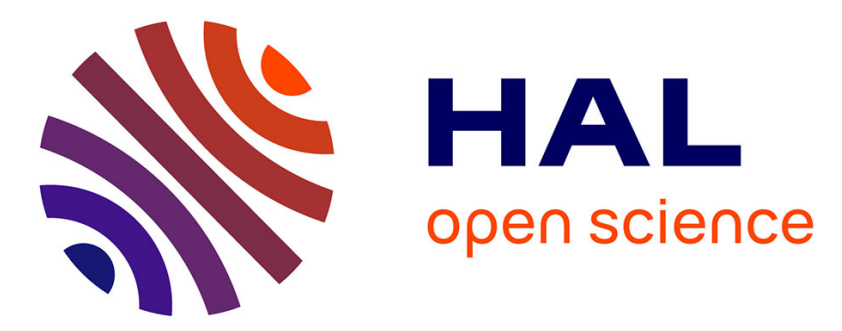

\title{
Still work and/or fun? -Corroboration of the hedonic and utilitarian shopping value scale
}

Karine Picot-Coupey, Nina Krey, Elodie Huré, Claire-Lise Ackermann

\section{To cite this version:}

Karine Picot-Coupey, Nina Krey, Elodie Huré, Claire-Lise Ackermann. Still work and/or fun? Corroboration of the hedonic and utilitarian shopping value scale. Journal of Business Research, 2021, 126, pp.578-590. 10.1016/j.jbusres.2019.12.018 . hal-02572817

\section{HAL Id: hal-02572817 https://hal-univ-rennes1.archives-ouvertes.fr/hal-02572817}

Submitted on 13 May 2020

HAL is a multi-disciplinary open access archive for the deposit and dissemination of scientific research documents, whether they are published or not. The documents may come from teaching and research institutions in France or abroad, or from public or private research centers.
L'archive ouverte pluridisciplinaire HAL, est destinée au dépôt et à la diffusion de documents scientifiques de niveau recherche, publiés ou non, émanant des établissements d'enseignement et de recherche français ou étrangers, des laboratoires publics ou privés. 


\title{
Still work and/or fun? - Corroboration of the hedonic and utilitarian shopping value scale
}

\author{
Karine Picot-Coupey ${ }^{a *} \bullet$ Nina Krey ${ }^{b}$ Elodie Huréc $\bullet$ Claire-Lise Ackermann ${ }^{d}$
}

Picot-Coupey, K., Krey, N., Huré, E., \& Ackermann, C. L. (2020). Still work and/or fun? Corroboration of the hedonic and utilitarian shopping value scale. Journal of Business Research, forthcoming, Available online 28 March 2020.

https://doi.org/10.1016/i.jbusres.2019.12.018

${ }^{a}$ (corresponding author), Univ Rennes, CNRS, CREM UMR 6211, F-35000 Rennes, France, University of Rennes 1 Graduate School of Management,11 Rue Jean Macé, CS 70803, 35708 Rennes, email: karine.picot@univ-rennes1.fr, +33 (0)2 232378 27, France.

${ }^{\mathrm{b}}$ Department of Marketing and Business Information Systems, Rohrer College of Business, Rowan University, 201 Mullica Hill Road, Glassboro, New Jersey 08028, email: krey@rowan.edu, phone: +1 856-256-4286, USA.

${ }^{\mathrm{c}}$ Rennes School of Business, 2 Rue Robert d'Arbrissel, CS 76522, 35065 Rennes Cedex, email: elodie.hure@rennes-sb.com, phone+33 (0)2 993946 84, France.

${ }^{d}$ Rennes School of Business, 2 Rue Robert d'Arbrissel, CS 76522, 35065 Rennes Cedex, email: claire-lise.ackermann@ennes-sb.com, phone: +33 (0)2 993348 81, France.

Acknowledgements: We would like to extend our gratitude to the original authors for providing support and additional information when needed. We appreciate the contribution of Lauren Brewer during the research process. In addition, we thank the hosts, reviewers, and participants of the 2018 AMS World Marketing Congress Corroborating Empirical Evidence Workshop for their insightful feedback and input. Finally, we thank the guest editors and two anonymous $J B R$ reviewers for their insightful comments. 


\title{
Still work and/or fun? Corroboration of the hedonic and utilitarian shopping value scale
}

\begin{abstract}
One of the most applied value scales in research is personal shopping value (PSV) by Babin, Darden, and Griffin (1994). PSV assesses consumers' shopping experiences along hedonic and utilitarian value. The purpose of this research is the corroboration of the original article and the PSV scale to investigate the impact of the past 25 years on the scale's dimensionality and item composition. The corroboration mirrors the original store environment, while an extension additionally considers two contemporary shopping environments: online websites and mobile apps. Results across six studies confirm shopping value's two-dimensional structure of work and fun. However, individual items capturing hedonic and utilitarian value deviate from original PSV scale items in number and nature for current stores, online, and mobile apps environments. Researchers and practitioners should exhibit caution to blindly administer or adapt measures without considering temporal or contextual aspects of the scale that limit its applicability.
\end{abstract} Keywords: Hedonic and Utilitarian value; Store; Online shopping; Mobile app 


\section{Introduction}

Value is one of the most prominently studied concepts in marketing (Leroi-Werelds, Streukens, Brady, \& Swinnen, 2014). Subsequently, shopping value is one of its key extensions assessing influential elements in consumption environments that shape consumers' shopping experiences (Gallarza, Gil-Saura, \& Holbrook, 2011). The concept of shopping value has been refined since the early 1990s, and a multitude of conceptualizations and scales have been proposed (Sánchez-Fernández \& Iniesta-Bonillo, 2007). Based on number and continuous increase in citations (5601 times [23 April 2018], 6056 [30 November 2018], 6210 [24 June 2019], 6491 [27 October 2019]), the most popular shopping value scale to this day is Babin, Darden, and Griffin (1994) scale. The authors introduce a parsimonious 15-item scale of personal shopping value (PSV), which assesses consumers' shopping experiences along hedonic and utilitarian value.

Since its introduction in 1994, the scale's applicability spans across numerous shopping environments (e.g., store; Stoel, Wickliffe, \& Lee, 2004; online; Bridges \& Florsheim, 2008), different countries (e.g., Germany, Austria, and Switzerland; Sirakaya-Turk, Ekinci, \& Martin, 2015), and various store types (e.g., discount stores; Carpenter, 2008; hypermarkets; Atulkar \& Kesari, 2017). Researchers also study PSV along multiple constructs including satisfaction, pleasure-arousal-dominance (P-A-D), word-of-mouth, and repatronage intentions (Jones, Reynolds, \& Arnold, 2006; Mehrabian \& Russell, 1974 ; Stoel et al., 2004); and even add to the original dimensions (e.g., social value; Rintamäki, Kanto, Kuusela, \& Spence, 2006). This comprehensive application of the PSV scale across different research areas illustrates its fundamental role and contribution to the literature. Despite its undeniable impact, a comprehensive corroboration of the original article to determine the PSV scale's continuous representation of shopping value in present retail environments remains absent from the marketing literature. The 
purpose of the current research is to explore whether the 15 PSV items and the scale's dimensionality still capture value in today's shopping environments. The first part of the research focuses on corroborating 20 available PSV items by following common scale development procedures and considering current store shopping experiences in line with Babin et al. (1994). The second part extents the original research by examining the scale items generalizability in digital shopping environments, namely online websites and mobile apps.

This article's contributions hinge on the assessment of the original PSV scale's generalizability in current stores and new retail contexts. Results confirm consumers' stable value assessments across different environments, yet how consumers extract value evolves over time and varies across retail settings. This shift manifests in the diverging number and nature of items capturing value today versus 25 years ago.

\section{Reflection of hedonic and utilitarian value scale application over time}

Building on Holbrook and Hirschman's (1982) view of consumption as an experience, Babin et al. (1994) position shopping value as the key outcome of shopping experiences. Consistent with the general view of value in the literature (Leroi-Werelds et al., 2014), the authors consider two types of value: hedonic and utilitarian value. The utilitarian dimension reflects rational, instrumental, and task-related shopping, thus shopping as a means to an end. The hedonic dimension corresponds to affective, emotional, and entertaining shopping, viewing shopping as an end in itself. The authors empirically develop and validate the PSV scale using a US sample in a typical mid-1990s shopping environment: physical store. The final scale consists of 15 items; 11 hedonic and 4 utilitarian value items.

A review of the marketing literature shows that this two-dimensional value structure is almost ubiquitous in shopping value research (Gallarza et al., 2011). It constitutes a reference point 
for an entire research stream that has been developing over the past 25 years. Researchers keep adopting the essence of the PSV scale, relying on its two dimensions and its content. Babin et al.'s (1994) research continues to act as a motivator for most other constructs or scales relating to shopping value (Overby \& Lee, 2006; Rintamäki et al., 2006).

A closer look into empirical studies reveals that researchers commonly shorten number of items per dimension (e.g., Garaus, Wagner, \& Kummer, 2015; Ozturk, Nusair, Okumus, \& Hua, 2016) or use non-data driven approaches to adapt wording of original scale items to fit specific research contexts (e.g., Atulkar \& Kesari, 2017). For example, a quick review of five randomly sampled articles assessing PSV in online shopping environments identifies a range of two to six items capturing value (Chen, Chang, \& Chen, 2017; Etemad-Sajadi \& Ghachem, 2015; Ozturk et al., 2016; Scarpi, Pizzi, \& Visentin, 2014; Wang, Baker, Wagner, \& Wakefield, 2007). Item wording also reflects inconsistencies; items such as "The interaction with the virtual agent is funny," "Using MHB is enjoyable," and "Browsing Fashion Guide is more joyful than other things $I d o "$ capture fun or joy of hedonic value at the authors' discretion (Chen et al., 2017; EtemadSajadi \& Ghachem, 2015; Ozturk et al., 2016). Considering that these adapted hedonic items seemingly omit common scale development procedures, the diverse item wording raises concerns of capturing the original PSV domain. Nevertheless, these continuous PSV scale adjustments to fit researchers' needs suggest that the original scale does not fully align with current research demands and consumer shopping behaviors.

From a methodology perspective, multi-item measures comprehensively capture the essence of a construct. Adapting item wording to better fit the context of investigation leads to a new scale, which should follow standard steps of scale development and refinement (Ortinau, 2011). Otherwise researchers might risk assessing constructs with multiple single-item measures 
rather than multiple-indicators, which can interfere with the validity of the results and overall conclusions (DeVellis, 2016; Gerbing \& Anderson, 1988). Additionally, the PSV scale was developed in a store context to capture physical store shopping value. According to Babin et al. (1994), administering the scale in a different retail environment reflects a scale adaptation that requires careful consideration of the original scale domain and underlying theory to ensure applicability of scale items in these new contexts.

Consumers shopping behaviors have transformed and fundamentally changed since the 1990s (Treadgold \& Reynolds, 2016). At that time, retail environments and shopping experiences primarily evolved around physical stores. Subsequently, shopping value derived mainly from visits to stores. With the emergence of online shopping in the early 2000s, digital multi-channel retailing started to develop and continues to grow; most recently through the introduction of smartphones (Fulgoni, 2014). While stores still remain important shopping outlets for consumers, shopping experiences continue to fragment more today than in 1994 and increasingly involve digital experiences across channels such as websites and mobile apps. Rather than engaging in a single shopping experience, multiple experiences across channels culminate to a seamless and comprehensive shopping journey (Verhoef, Kannan, \& Inman, 2015). These experiences and channels, such as websites, mobile applications, and stores, can be utilized successively, simultaneously, or alternately (Treadgold \& Reynolds, 2016). For example, consumers browsing in a store might compare prices on multiple websites on their smartphones and ultimately utilize an app to complete the purchase. Thus, the boundaries of individual channels might not be clearly distinguishable but rather intertwine in creating a consumer experience (Verhoef et al., 2015). Successful retail strategies mirror these developments and focus on streamlining channel communications, image management, and service delivery to offer a consistent consumer 
experience within a comprehensive retail ecosystem (Aubrey \& Judge, 2012). Considering that "shopping value is (...) characterized by consumers' interactions with an environment" (Babin et al., 1994, p. 654), understanding consumer experiences and value in these new online and mobile retail environments is critical (Huré, Picot-Coupey, \& Ackermann, 2017). Yet Babin et al. (1994) suggest that scale items might deviate across these environments and that adaptation to other consumption contexts is advisable.

Therefore, this research follows Tsang and Kwan's (1999) broad approach of corroboration by applying the original PSV scale to a different population while adhering to original data analyses procedures, incorporating updated methodologies, and considering current contextual factors. This reassessment and extension of a conceptually and historically very important, highlycited and highly-administered scale examines if construct validity persists today in contemporary contexts (Kerr, Schultz, Kitchen, Mulhern, \& Beede, 2015).

\section{Corroboration methodology of scale development procedures}

The original article administers common scale development procedures still applicable today (Churchill, 1979; Gerbing \& Anderson, 1988). The authors generate an initial 71 item pool based on comprehensive literature reviews and focus group interviews. After initial item purification to 53 items through exploratory factor analysis (EFA) and confirmatory factor analysis (CFA), 20 items remain for final assessment. CFA validation confirms 15 final PSV items representing store shopping value. The present research mirrors the original scale development approach including scale refinement, reliability, and validity assessments. In addition, assessment explores similarities and differences of newly identified and original PSV items.

The corroboration incorporates contemporary sampling approaches by utilizing third party panel data matching current US census demographics. Consistent with the original research, it also 
focuses on recent in-store shopping experiences. Consumers who do not remember timing of shopping experience are automatically excluded from the study. In addition, screening of shopping experiences ensures exclusion of grocery shopping trips in line with the original study. Table 1 compares and contrasts the original methodology with the corroboration process.

[Please insert Table 1 about here]

\subsection{Study 1: Corroboration of initial scale development}

Study 1 explores item purification by identifying potential items for deletion. Drawing from a representative US online panel collected by a professional company, the final sample consisted of 171 consumers (female $=69 \%$; male $=31 \%$; mean $_{\text {age }}=37$; annual income of $\$ 20,000$ $\$ 79,999=59 \%$ ) residing in the US. 116 respondents reported an experience in a store within a week of completing the questionnaire (today $=7 \% ; 1-2$ days $=26 \% ; 3-6$ days $=34 \%$ ). Appendix A provides an overview of this sample and additional samples included in this research.

Since the initial set of 53 shopping value items was unavailable, participants responded to 20 initial items. The survey also included an open-ended question asking participants to briefly discuss their shopping experience, control variables (frequency of shopping in a store; number of last 10 purchases completed in a store), and demographic questions. The final sample included 171 complete responses. Where appropriate, all corroboration and extension measures included fivepoint Likert scales (Babin et al., 1994).

\subsubsection{Confirmatory factor analysis}

CFA with appropriate constraints applied to the covariance matrix offers a suitable tool to examine psychometric properties (Hair, Babin, \& Krey, 2017). Using Amos 24 and maximum likelihood estimation, CFA considering all 20 original items reveals six items with low factor loadings or standardized residuals. Upon removing these six items, final CFA results in a $\chi^{2}$-value 
of $128.7(d f=76, \mathrm{p}<0.001)$, a comparative fit index $(\mathrm{CFI})$ of 0.95 , a root mean square error of approximation (RMSEA) of 0.06, a normed fit index (NFI) of 0.89 , and a goodness-of-fit (GFI) of 0.90. These fit statistics indicate good model fit. Average variance extracted (AVE) and reliability levels assess discriminant validity. AVEs are above 0.50 (0.57 and 0.61$)$ and exceed the square of the corresponding correlation estimates between the two factors (0.02) (Fornell \& Larcker, 1981). Factors also display acceptable reliability levels $(\alpha=0.91$ and $\alpha=0.77$ for hedonic and utilitarian value respectively). In accordance with more recent reporting standards, composite reliability (C.R.) values exceed the threshold of 0.70 with 0.93 for hedonic value and 0.86 for utilitarian value (Hair et al., 2017). Overall, discriminant validity is evident (see Table 2).

[Please insert Table 2 about here]

CFA estimates the original 15-item PSV scale to assess its performance given the current data. The overall model $\chi^{2}$ of $196.4(\mathrm{df}=89, \mathrm{p}<0.001)$ and corresponding CFI of 0.90 , RMSEA of 0.08, NFI of 0.84 , and GFI of 0.86 all suggest reasonable model fit (Hair, Black, Babin, \& Anderson, 2010). The overall fit of the new model is better than the fit of the original model indicating that the new selection of items more accurately captures hedonic and utilitarian value for current store shopping environments (details in Table 2).

\subsubsection{Convergent validity}

Convergent validity assessment follows original study procedures involving written shopping descriptions of respondents. Two judges independently rate each description on a threepoint scale (low/average/high) according to its utilitarian and hedonic value content. High interjudge agreement provides a first positive assessment with exact agreement for hedonic rating of $74 \%$ (126 of 171$)$ and $82 \%$ (140 of 171) for utilitarian rating. The two judges only express complete disagreement for two hedonic and two utilitarian ratings. A third judge provides 
additional feedback to resolve the disagreement. Overall, high consistency between judge's evaluations prevails. Analysis of respondents' descriptions confirms that hedonic and utilitarian value still emerge in today's store shopping experiences as it did in the early 1990s.

Utilizing judges' ratings as treatment levels and respondent's hedonic/utilitarian value summed factor scores as dependent variables, analysis of separate single-factor ANOVA models follows. The first model displays a significant effect for hedonic ratings on hedonic value $\left(\mathrm{F}(2,168)=16.09, \mathrm{p}<0.001 ;\right.$ mean $_{\text {low }}=33.07$, mean $\left._{\text {high }}=41.32\right)$. The second model shows the effect of utilitarian ratings on utilitarian value, which are not significant $(F(2,168)=1.62, p=0.201$; mean $_{\text {low }}=14.35$, mean $_{\text {high }}=14.95$ ). Results confirm consistency between judges' evaluations of open-ended respondent descriptions and self-report scores of hedonic and utilitarian value.

\subsubsection{Discussion}

Initial results corroborate the two-dimensional structure of the PSV scale - with a few deviations. Whereas the initial PSV scale includes 15 items, 14 items improve fit for the current sample. These preliminary results suggest that consumers do express differences in shopping experiences in stores today compared to 25 years ago.

\subsection{Study 2: Corroboration of scale validation}

Study 2 validates the remaining items with a different sample (Gerbing \& Anderson, 1988). The same online panel company from study 1 surveyed 151 participants (female $=56 \%$; male $=44 \%$; mean $_{\text {age }}=39$; annual income of $\$ 20,000-\$ 79,999=59 \%$ ) residing in the US (see Appendix A). 114 participants completed a store shopping experience within a week of responding to the survey (today $=8 \% ; 1-2$ days $=20 \% ; 3-5$ days $=48 \%$ ).

The questionnaire consisted of the same measures as the previous one, except for the openended question about the shopping experience. Instead, the survey included constructs consistent 
with Babin and colleagues (1994) to assess nomological validity: P-A-D (Mehrabian \& Russell, 1974), bargain perceptions (Babin et al., 1994), original intention of purchase (yes/no; Babin et al., 1994), total amount spent (single item), unplanned purchases (single item, amount of planned/unplanned purchases; Babin et al., 1994), time pressure (Herrington, 1996), satisfaction (Maxham \& Netmeyer, 2002), experiential shopping motivation (Attaway, 1989), and compulsive buying tendencies (Faber \& O'Guinn, 1992). Three new constructs of interest repatronage intentions (Jones et al., 2006; Stoel et al., 2004), word-of-mouth (Jones et al., 2006), and flow i.e. complete engagement with and immersion in an activity (Novak, Hoffman, \& Yung, 2000; Wang et al., 2007) plus demographic questions completed the survey. The final sample encompassed 151 respondents.

\subsubsection{Confirmatory factor analysis results}

CFA validates the remaining 14 items yielding a $\chi^{2}$ of $206.7(d f=76, \mathrm{p}<0.001)$. The corresponding $\mathrm{CFI}=0.94, \mathrm{RMSEA}=0.07, \mathrm{NFI}=0.90$, and $\mathrm{GFI}=0.92$ reflect good fit. $\mathrm{AVEs}$ for each factor are above $0.50(0.52$ and 0.63$)$ and exceed the square of the corresponding correlation estimates between the two factors (0.04) (Fornell \& Larcker, 1981). All factor loadings surpass established cut-off value of 0.50 (Hair et al., 2010). Each factor also displays acceptable reliability levels ( $\alpha=0.90$ and $\alpha=0.77$ for hedonic and utilitarian value respectively) and C.R. values exceed 0.70 threshold (Hair et al., 2017). In sum, results provide further evidence of convergent and discriminant validity.

When comparing overall scale assessment and measurement values of the new 14 items to the original 15 items, the 14 -item scale provides better fit statistics with the current data $\left(\chi^{2}=278.6\right.$; $\mathrm{df}=89 ; \mathrm{p}<0.001 ; \mathrm{CFI}=0.90 ; \mathrm{RMSEA}=0.08 ; \mathrm{NFI}=0.84 ; \mathrm{GFI}=0.89$; see Table 2). 


\subsubsection{Nomological validity - previous measures}

Nomological validity assessment includes the same measures and proposed relationships as in the original paper including experiential shopping motivation, compulsive buying, pleasure, arousal, bargain perception, amount spent, unplanned purchases, time pressure, and overall satisfaction (Babin et al., 1994). Table 3 depicts all correlation estimates for nomological validity assessment.

[Please insert Table 3 about here]

Consumers can express either task- or experiential-oriented shopping motivations, which aligns with utilitarian and hedonic value (Babin et al., 1994). The current study replicates previous results observing positive correlations between experiential shopping motivation and hedonic value $\left(\mathrm{r}_{\mathrm{hv}}=0.56, \mathrm{p}<0.001\right)$. In addition, consumers may express different compulsive buying tendencies, which often lead to heightened mood (Faber \& O'Guinn, 1992; Flight, Rountree, \& Beatty, 2012). While the original article establishes a positive relationship between compulsiveness and hedonic value, current correlation results do not confirm this relationship. Both studies reveal no association between compulsiveness and utilitarian value.

The relationship between emotions and value has a long history in retailing (Bloch \& Bruce, 1984). Two prominently studied emotions are pleasure and arousal based on the P-A-D framework by Mehrabian and Russell (1974). Empirical results available in Babin et al. (1994) suggest pleasure and arousal to positively relate with hedonic and utilitarian value. As predicted in the original article and in current research (Wang et al., 2007), the relationship between utilitarian value and both emotions is often weaker than their relationship with hedonic value as it is more complex. Current results support this reasoning. Both hedonic and utilitarian value 
positively correlate with pleasure $\left(\mathrm{r}_{\mathrm{hv}}=0.67, \mathrm{p}<0.001 ; \mathrm{r}_{\mathrm{uv}}=0.50, \mathrm{p}<0.001\right)$ and arousal $\left(\mathrm{r}_{\mathrm{hv}}=0.59\right.$, $\left.\mathrm{p}<0.001 ; \mathrm{r}_{\mathrm{uv}}=0.30, \mathrm{p}<0.001\right)$.

Bargain perceptions relate to price discounts (utilitarian value) or feelings of being a smart shopper (hedonic value) (Green Atkins \& Kim, 2012). Present attempts corroborate Babin et al.'s (1994) results: consumers' bargain perceptions positively relate to hedonic $\left(\mathrm{r}_{\mathrm{hv}}=0.34, \mathrm{p}<0.001\right)$ and utilitarian $\left(\mathrm{r}_{\mathrm{uv}}=0.26, \mathrm{p}<0.010\right)$ value.

Two additional single-item spending behavior measures are total amount spent and unplanned purchases. Here, efficient completion of a shopping task increases utilitarian value, while self-rewarding spending drives hedonic value (Bloch \& Bruce, 1984). Total amount spent positively relates to both value dimensions in the original article; current findings do not confirm these relationships. Unplanned purchases conceptually equate with impulsive buying enhancing hedonic and lowering utilitarian value (Rook, 1987). While the original authors support the relationship for hedonic and not for utilitarian value, this study only confirms that unplanned purchases do not relate to utilitarian value.

The time pressure consumers may experience during shopping can diminish hedonic value by decreasing feelings of freedom and spontaneity (Babin et al., 1994). It can also lead to higher perceived cost of information search and potential regret of decisions in the future (Hoch \& Loewenstein, 1991). Consistent with prior findings, perceived time pressure negatively correlates with hedonic $\left(\mathrm{r}_{\mathrm{hv}}=-0.36, \mathrm{p}<0.001\right)$ and utilitarian $\left(\mathrm{r}_{\mathrm{uv}}=-0.39, \mathrm{p}<0.001\right)$ value. Lastly, consumer satisfaction should positively relate to both value dimensions. While a single-item index of satisfaction originally captured overall satisfaction, the current study utilizes a contemporary multi-item measure (Maxham \& Netemeyer, 2002). Results confirm customer satisfaction's relationship with hedonic $\left(\mathrm{r}_{\mathrm{hv}}=0.50, \mathrm{p}<0.001\right)$ and utilitarian $\left(\mathrm{r}_{\mathrm{uv}}=0.56, \mathrm{p}<0.001\right)$ value. 
While not all measures reveal significant relationships with hedonic and utilitarian value, there is overall support for nomological validity.

\subsubsection{Nomological validity - contemporary measures}

More recent constructs studied with value contribute to further assess nomological validity: repatronage intentions, word-of-mouth, and flow (Atulkar \& Kesari, 2017; Jones et al., 2006; Overby \& Lee, 2006; Stoel et al., 2004; Wang et al., 2007). Repatronage intentions reflect the likelihood that customers will shop at a store again and relate to both value dimensions (Stoel et al., 2004). Empirical evidence equates affective shopping experiences, materialized by hedonic value, to antecedents of approach behaviors including repatronage intentions (Jones et al., 2006). Utilitarian perceptions of effectively accomplishing a shopping task also increase repatronage intentions (Jones et al., 2006). Present findings support previous expectations since repatronage intentions correlate with hedonic $\left(\mathrm{r}_{\mathrm{hv}}=0.39, \mathrm{p}<0.001\right)$ and utilitarian $\left(\mathrm{r}_{\mathrm{uv}}=0.30, \mathrm{p}<0.001\right)$ value.

Word-of-mouth is a consequence of emotional or pleasurable responses to consumption situations that consumers can relieve by sharing experiences with others (Jones et al., 2006). Previous studies identify relationships between word-of-mouth and both value dimensions (Chevalier \& Mayzlin, 2006). Results show association between word-of-mouth and these dimensions $\left(\mathrm{r}_{\mathrm{hv}}=0.32, \mathrm{p}<0.001 ; \mathrm{r}_{\mathrm{uv}}=0.43, \mathrm{p}<0.001\right)$.

Flow is a psychological state that blends actions and awareness with intense concentration that fully engages an individual with his or her interaction with a computer (Hoffman \& Novak, 1996; 2009). It consists of four dimensions: interest, curiosity, control, and attention (Novak, Hoffman, \& Yung, 2000). Wang et al. (2007) relate flow to utilitarian and hedonic value in online shopping contexts. Since flow involves feelings of curiosity and interest in an activity or task, it positively relates to hedonic value (Wang et al., 2007). Results support correlations between 
interest, curiosity, attention, and control dimensions of flow and hedonic value (interest: $\mathrm{r}_{\mathrm{hv}}=0.71$, $\mathrm{p}<0.001$; curiosity: $\mathrm{r}_{\mathrm{hv}}=0.59, \mathrm{p}<0.001$; attention: $\mathrm{r}_{\mathrm{hv}}=-0.19, \mathrm{p}<0.001$; control: $\left.\mathrm{r}_{\mathrm{hv}}=0.40, \mathrm{p}<0.001\right)$. Only interest and control of flow associate with utilitarian value (interest: $r_{u v}=0.26, p<0.010$; control: $\left.\mathrm{r}_{\mathrm{uv}}=0.39, \mathrm{p}<0.001\right)$. Overall, results further suggest nomological validity.

\subsubsection{Corroboration of fulfilling original intentions}

The fulfillment of product acquisition intentions aligns with accomplishing a task and relates more with utilitarian than hedonic value. A one-way ANOVA tests this relationship by using respondents' yes/no answers of originally intended product purchases as an independent variable. Respondents summed hedonic and utilitarian value scores act as the dependent variable. Results support the relationship between product acquisition intention and utilitarian value $\left(F(1,133)=27.86, p<0.001, R^{2}=0.17\right)$. Respondents purchasing originally intended items report a higher level of utilitarian value (mean=17.6) than respondents not purchasing these items (mean=13.8). The relationship is not significant for hedonic value $(F(1,133)=0.07, p=0.798$, $\left.\mathrm{R}^{2}=0.01\right)$

\subsection{Preliminary corroboration summary}

Corroboration results provide continuous support for the two-dimensional structure of the PSV scale from 1994. In contrast to the original 15-item scale, CFA on two different samples identify a 14-item solution best representing hedonic (10 items) and utilitarian (4 items) value. Thus, different items capture the domain of the shopping value construct for today's store shopping experiences. Items kept and/or dropped from the initial 20 items differ from the items retained by Babin et al. (1994). Items eliminated from the original scale are: $1_{\text {hv }}$ I continued to shop, not because I had to, but because I wanted to, $2 \mathrm{hv}$ ) This shopping trip was not a very nice time out, $3_{\mathrm{uv}}$ I was disappointed because I had to go to another store(s) to complete my shopping. New 
items added from the initial 20 items include: $1_{\text {hv }}$ I was able to do a lot of fantasizing during the trip and $2_{\mathrm{uv}}$ ) I think this shopping trip was successful. The corroboration results also support nomological validity not only for previously assessed measures, but also for constructs relevant in current value studies.

The new 14 items outperform the original 15 items in study 1 and study 2 , suggesting that the original scale should be cautiously administered in current store contexts as consumer behavior does seem to have changed. Considering the different nature of current retail environments, a typical shopping experience in 2019 may not encompass the same elements as in 1994.

While shopping at a store most certainly contributed to shopping experiences in the past, the same is not necessarily true today since consumers commonly rely on additional retail channels, such as websites and mobile apps (Aubrey \& Judge, 2012). Consumer shopping experiences frequently include a digital starting point or combine visits to multiple different websites or mobile applications into one consumption experience. The scale assessment reflects these developments since not all original hedonic and utilitarian value scale items translate to contemporary store environments. Therefore, considering additional consumption environments aligns more accurately with current consumer behavior as omni-channel shoppers (Verhoef et al., 2015). The next part of the study shifts to an extension by incorporating online and mobile app shopping contexts.

\section{Extension of hedonic and utilitarian value scale}

The scale extension studies apply the same scale development and validation procedures, data collection approach, questionnaire design, original 20 PSV items, nomological validity assessment, and demographic questions to allow comparability of results while incorporating online and mobile app shopping experiences. Since the purpose of this research is to compare and 
corroborate original items across new contexts rather than to develop new context-specific value scales, this extension analysis excludes item adaptation. Item modification or adaptation would not allow assessment of PSV scale item's generalizability via multi-group CFA as the original Babin et al. (1994) scale would have been replaced with an assembly of new items (DeVellis, 2016; Ortinau, 2011).

\subsection{Extension of hedonic and utilitarian value scale to online context}

Since the late 1990s, online shopping is gaining popularity in the US (Mosteller, Donthu, \& Eroglu, 2014). With technological advancements improving online shopping experiences, it is now an important and routine shopping environment (Zhou, Dai, \& Zhang, 2007). Considering this increased relevance of online shopping, the next two studies focus on assessing PSV items in an online context.

\subsubsection{Study 3: Extension of initial scale development to online context}

Similar to study 1 , study 3 utilizes CFA to examine psychometric properties of the scale to identify initial items suitable for an online shopping context. The final panel sample consisted of 142 US consumers (female $=43 \%$; male $=57 \%$; mean $_{\text {age }}=40$; annual income of $\$ 20,000$ $\$ 79,999=61 \%$; see Appendix A). Participants first responded to the 20 initial shopping value items and then discussed their online shopping experience. In line with the corroboration study, the sample only included respondents with recent shopping experiences who provided details such as items purchased, time and length of shopping trip, shopping companion, and shopping motivation.

The online survey also included questions about type of website used for the shopping experience, comfort level associated with using technology (Overby \& Lee, 2006), frequency of Internet usage (Porter \& Donthu, 2006), and frequency of utilizing online websites for shopping. 
The survey ended with several demographic questions. Elimination of incomplete responses finalized the sample.

\subsubsection{Confirmatory factor analysis}

For online context, CFA estimation with 20 items identifies six items for removal due to low factor loadings and residuals. The remaining 14 items are subject to a second CFA resulting in a $\chi^{2}$-value of $130.8(d f=76, \mathrm{p}<0.001)$, CFI of 0.94 , RMSEA of 0.07 , NFI of 0.87 , and GFI of 0.87. These statistics indicate good fit (Hair et al., 2010).

AVEs are above $0.50(0.57$ and 0.64$)$ and exceed the square of the corresponding correlation estimates between the two factors (0.01) (Fornell \& Larcker, 1981). Factor loadings surpass the cutoff value of 0.50 for all items (Hair et al., 2010). Both factors indicate acceptable reliability levels ( $\alpha=0.91$ and $\alpha=0.79$ for hedonic and utilitarian value respectively) and corresponding C.R. values are 0.93 and 0.88 (Hair et al., 2017). Results provide evidence of convergent and discriminant validity. Table 4 summarizes results of this analysis.

[Please insert Table 4 about here]

\subsubsection{Study 4: Extension of scale validation to online context}

The purpose of study 4 is the validation of the 14 items assessing hedonic and utilitarian value in an online context. It also examines nomological validity.

A total of 161 US consumers comprised the final sample for online context (female $=48 \%$; male $=52 \%$; mean $_{\text {age }}=43$; annual income of $\$ 20,000-\$ 79,999=61 \%$; see Appendix A). Study 4 followed the same methodology as study 2 , yet respondents referred to a recent online shopping experience. The online survey was consistent with study 2 plus included items related to website shopping experience (see study 3 ). The survey concluded with demographic questions and again, the final sample eliminated incomplete responses. 


\subsubsection{Confirmatory factor analysis}

CFA estimate the previously identified 14 items. Results produce a significant $\chi^{2}$ of 202.9 with 76 degrees of freedom $(p<0.001)$. The CFI of 0.94 , RMSEA of 0.07 , NFI of 0.90 , and GFI of 0.91 indicate good model fit. AVE values are 0.61 for hedonic and 0.45 for utilitarian value and exceed the square of the corresponding correlation estimates between the two factors $(0.02)$ (Fornell \& Larcker, 1981). As Table 4 depicts, factor loadings surpass the cutoff value of 0.50 (Hair et al., 2010). Reliability and C.R. values exceed expected thresholds (hedonic value: $\alpha=0.92$, C.R. $=0.93$; utilitarian value: $\alpha=0.71$, C.R. $=0.74$ ) (Hair et al., 2017). Results provide evidence of convergent and discriminant validity.

\subsubsection{Nomological validity assessment}

Nomological validity assessment for the 14 PSV items replicates measures and procedures of the corroboration validity examination. While Table 3 outlines details for all correlation results, the succeeding discussion focuses on the most relevant results for online context: pleasure, arousal, satisfaction, word-of-mouth, repatronage intentions, and flow (Atulkar \& Kesari, 2017; Jones et al., 2006; Overby \& Lee, 2006; Stoel et al., 2004; Wang et al., 2007). The previous discussions in sections 3.2.2. and 3.2.3. suggest positive relationships for both value dimensions and aforementioned measures.

Results reveal association between hedonic value and pleasure $\left(\mathrm{r}_{\mathrm{hv}}=0.52, \mathrm{p}<0.001\right)$, arousal $\left(\mathrm{r}_{\mathrm{hv}}=0.57, \mathrm{p}<0.001\right)$, satisfaction $\left(\mathrm{r}_{\mathrm{hv}}=0.46, \mathrm{p}<0.001\right)$, repatronage intentions $\left(\mathrm{r}_{\mathrm{hv}}=0.37, \mathrm{p}<0.001\right)$, word-of-mouth $\left(\mathrm{r}_{\mathrm{hv}}=0.37, \mathrm{p}<0.001\right)$, and each dimension of flow (interest: $\mathrm{r}_{\mathrm{hv}}=0.70, \mathrm{p}<0.001$; curiosity: $\mathrm{r}_{\mathrm{hv}}=0.73, \mathrm{p}<0.001$; attention: $\mathrm{r}_{\mathrm{hv}}=0.44, \mathrm{p}<0.010$; control: $\mathrm{r}_{\mathrm{hv}}=0.45, \mathrm{p}<0.001$ ). Further, utilitarian value correlates with pleasure $\left(\mathrm{r}_{\mathrm{uv}}=0.27, \mathrm{p}<0.050\right)$, satisfaction $\left(\mathrm{r}_{\mathrm{uv}}=0.34, \mathrm{p}<0.001\right)$, word-of-mouth $\left(\mathrm{r}_{\mathrm{uv}}=0.19, \mathrm{p}<0.050\right)$, and three dimensions of flow (interest: $\mathrm{r}_{\mathrm{uv}}=0.21, \mathrm{p}<0.010$; 
attention: $\mathrm{r}_{\mathrm{uv}}=0.24, \mathrm{p}<0.010$; control: $\left.\mathrm{r}_{\mathrm{uv}}=0.28, \mathrm{p}<0.001\right)$. Utilitarian value does not related to arousal, as would be expected.

\subsubsection{Preliminary online extension summary}

Results extend the two-dimensional structure of the PSV scale to an online context; however, only 14 rather than 15 items represent value in online shopping environments. Interestingly, the scale purification process identifies different items for retention and elimination in the current study versus 25 years ago. For online context, items no longer representing shopping value include: $\left.1_{\mathrm{hv}}\right)$ While shopping, I was able to forget my problems, $\left.2_{\mathrm{hv}}\right)$ This shopping trip was not a very nice time out, and $3_{\mathrm{uv}}$ ) While shopping, I found just the item(s) I was looking for. Items added from the initial 20 items include: $1_{\text {hv }}$ I was able to do a lot of fantasizing during this trip and $2_{\text {uv }}$ I feel this shopping trip was successful. While 14 items also assess value in current store experiences, individual items differ across both contexts.

\subsection{Extension of hedonic and utilitarian value scale to mobile app context}

Even though the trend might still be in its infancy, consumers increasingly turn towards mobile apps and mobile shopping (Kim, Yoon, \& Han, 2016). Consequently, mobile app shopping is quickly developing into an important new shopping context especially for younger consumers (Taylor \& Lewin, 2014). An extension of consumer value perceptions to a mobile app context follows.

\subsubsection{Study 5: Extension of initial scale development to mobile app context}

Study 5 focuses on extending the initial scale development procedure to a mobile app context and mirrors extension study 3 . The same professional panel company surveyed 138 US consumers (female $=54 \%$; male $=46 \%$; mean $_{\text {age }}=29$; annual income of $\$ 20,000-\$ 79,999=37 \%$ ). The survey included 20 initial PSV items and controlled for recency of a mobile app shopping 
experience. Specifically, participants responded to the same questions as for the online context including type of mobile apps used for the shopping experience, comfort level associated with using technology (Overby \& Lee, 2006), frequency of mobile app usage (Porter \& Donthu, 2006), frequency of utilizing mobile apps for shopping, and demographic questions. The final sample excluded incomplete responses (see Appendix A).

\subsubsection{Confirmatory factor analysis}

Initial CFA estimation eliminates eight of the original 20 items based on low factor loadings and residuals. CFA on the remaining 12 items yields a $\chi^{2}$-value of $57.2(d f=53, \mathrm{p}<0.324)$, $\mathrm{CFI}=0.99, \mathrm{RMSEA}=0.03, \mathrm{NFI}=0.91$, and $\mathrm{GFI}=0.94$, reflecting excellent fit. AVEs are above 0.50 ( 0.53 and 0.65$)$ and exceed the square of the corresponding correlation estimates between the two factors (0.01) (Fornell \& Larcker, 1981). Both factors indicate acceptable reliability levels $(\alpha=0.86$ and $\alpha=0.81$ for hedonic and utilitarian value) and corresponding C.R. values surpass the 0.7 threshold with 0.90 and 0.88 (Hair et al., 2017). Factor loadings exceed the cutoff value of 0.50 for all items (Hair et al., 2010). The overall results confirm good discriminant and convergent validity. For details, consult Table 4.

\subsubsection{Study 6: Extension of scale validation to mobile app context}

Consistent with the previous analysis for online context (study 4), study 6 validates the 12 items for mobile app context and compares them to the original PSV scale. It also assesses nomological validity by including additional constructs of interest.

A sample of 141 US consumers $\left(38 \%\right.$ female; $62 \%$ male; mean $_{\text {age }}=25$; annual income of $\$ 20,000-\$ 79,999=54 \%$ ) was collected by a panel company (see Appendix A). The mobile app survey consisted of the same measures as study 2 and additional items related to mobile app shopping experience from study 5. Incomplete responses were again excluded from the sample. 


\subsubsection{Confirmatory factor analysis}

A final CFA estimates the remaining 12 items. Fit for the model is once again strong (see Table 4). The $\chi^{2}$-value is $108.3(d f=53, \mathrm{p}<0.001)$ yielding a CFI of 0.96 , a RMSEA of 0.06 , a NFI of 0.92 , and a GFI of 0.94 . Items reflect good psychometric properties meeting convergent and discriminant validity concerns based on factor loadings exceeding 0.50 , reliability values $(\alpha=0.87$ and $\alpha=0.78$ ), and C.R. values (C.R. $=0.90$ and C.R. $=0.84)$ for hedonic and utilitarian value respectively. AVE values are 0.55 and 0.57 . Once more AVE values exceed the square of the corresponding correlation estimates between the two factors (0.02) (Fornell \& Larcker, 1981).

\subsubsection{Nomological validity assessment}

Nomological validity assessment for the 12 items in a mobile app context mirror measures and procedures of the previous corroboration validity examination. The succeeding discussion focuses on the most relevant results for the mobile app context including pleasure, arousal, satisfaction, word-of-mouth, repatronage intentions, and flow (Atulkar \& Kesari, 2017; Overby \& Lee, 2006; Stoel et al., 2004; Wang et al., 2007), while Table 3 outlines details for all correlation results. The previous discussions in sections 3.2.2. and 3.2.3. suggest positive relationships between both value dimensions and aforementioned measures.

Results indicate positive relationships between hedonic value and pleasure $\left(\mathrm{r}_{\mathrm{hv}}=0.40\right.$, $\mathrm{p}<0.001)$, arousal $\left(\mathrm{r}_{\mathrm{hv}}=0.40, \mathrm{p}<0.001\right)$, satisfaction $\left(\mathrm{r}_{\mathrm{hv}}=0.47, \mathrm{p}<0.001\right)$, repatronage intentions $\left(\mathrm{r}_{\mathrm{hv}}=0.22, \mathrm{p}<0.010\right)$, word-of-mouth $\left(\mathrm{r}_{\mathrm{hv}}=0.36, \mathrm{p}<0.001\right)$, and three dimensions of flow (interest: $\mathrm{r}_{\mathrm{hv}}=0.61, \mathrm{p}<0.001$; curiosity: $\mathrm{r}_{\mathrm{hv}}=0.61, \mathrm{p}<0.001$; attention: $\left.\mathrm{r}_{\mathrm{hv}}=0.43, \mathrm{p}<0.001\right)$. In contrast, correlation estimates only show significance for relationships between utilitarian value and satisfaction $\left(\mathrm{r}_{\mathrm{uv}}=0.49, \mathrm{p}<0.001\right)$, repatronage intentions $\left(\mathrm{r}_{\mathrm{uv}}=0.24, \mathrm{p}<0.010\right)$, word-of-mouth 
$\left(r_{u v}=0.33, p<0.001\right)$, and interest dimension of flow (interest: $\left.r_{u v}=0.18, p<0.050\right)$. Results confirm nomological validity for the 12 items capturing value in a mobile app context.

\subsubsection{Preliminary app extension summary}

Results confirm PSV scale dimensionality for 12 instead of 15 items representing shopping value in mobile app shopping environments. Two studies identify items no longer representing shopping value in a mobile app context: $1_{\mathrm{hv}}$ ) I enjoyed being immersed in exciting new products, $2 \mathrm{hv})$ While shopping, I felt a sense of adventure, $\left.3_{\mathrm{hv}}\right)$ This shopping trip was not a very nice time out, and $4_{\mathrm{uv}}$ ) I was disappointed because I had to go to another store(s) to complete my shopping. One original scale item is added to the list of 12 items: $1_{\text {uv }}$ I feel this shopping trip was successful.

Overall, the various studies identify different items of the initial 20-item set to most accurately assess shopping value in different contexts. Every context drives a set of items that deviates in quantity and nature from the original 15-item PSV scale, namely 14 items for store, 14 items for online, and 12 items for mobile app (see Table 5 for details). These results substantiate the discrepancy between a measure developed 25 years ago and today's shopping experiences. Findings should further caution researchers to administer original or adapted scales in inconsistent contexts without following proper scale development procedures to guarantee face validity and accurate assessment of scale domain.

[Please insert Table 5 about here]

\subsection{Multi-group analysis}

Multi-group analysis is a suitable step in further validating a scale; therefore, multi-group CFA estimates covariance matrices of store, online, and mobile app samples (Babin, Borges, \& James, 2016; Hair et al., 2010). The PSV scale corroboration and scale extension results reflect diverging quantity and type of items driven by the nature of the shopping experience. 
Consequently, cross-validation analysis is limited to 9 items consistent across all contexts: hedonic value $1,2,3,4,6,8$ and utilitarian value $14,15,18$ (see Table 5 for item wording).

The assessment first focuses on store and online samples. The initial two-group CFA, or unconstrained model, assesses potential variation in factor loading pattern between groups. The model $\chi^{2}$-value is $84.30(d f=52, \mathrm{p}=0.003)$ with CFI of 0.97 , RMSEA of 0.05 , NFI of 0.93 , and GFI of 0.94 reflects good fit and stable factor pattern. To assess metric invariance, constraints are added forcing factor loading to take on the same value in both samples: store and online. Results of the CFA with the added constraints yield $\chi^{2}$ of $88.48(d f=59, \mathrm{p}=0.008)$, a CFI of 0.97 , a RMSEA of 0.04, a NFI of 0.92, and a GFI of 0.94. The $\chi^{2}$ difference between the two models is 4.18 with $7 \mathrm{df}$ and p-value of 0.759 , making it not significant. Thus, additional constraints do not hurt the fit with stable loadings across the shopping samples. Table 6 compares the different models.

[Please insert Table 6 about here]

A comparison of store and mobile app samples follows (see Table 6). The unconstrained model $\chi^{2}$-value is 78.38 with $52 \mathrm{df}(\mathrm{p}=0.010)$, yielding a CFI of 0.97 , a RMSEA of 0.04 , a NFI of 0.93, and a GFI of 0.97 . The fit statistics support the model and suggest a stable factor pattern. In terms of metric invariance, CFA with added constraints produces a $\chi^{2}$ of $86.02(d f=59, \mathrm{p}=0.012)$, a CFI of 0.97, a RMSEA of 0.04, a NFI of 0.92, and a GFI of 0.97 . The $\chi^{2}$ difference between the two models is 7.64 with $7 \mathrm{df}$ and p-value of 0.366 , making it not significant. This result shows that fit and loadings, despite the additional constraints, are stable across store and mobile app samples.

The final multi-group CFA assesses comparability of items across online and mobile app samples. The unconstrained model $\chi^{2}$ is $67.61(d f=52, \mathrm{p}=0.072)$ with a CFI of 0.99 , a RMSEA of 0.03, a NFI of 0.94 , and a GFI of 0.95 . These fit statistics again support good fit and indicate that the factor pattern remains the same. Metric invariance for online and mobile app samples is 
assessed and supported as CFA results with added constraints yield $\chi^{2}$ of $72.86(d f=59, \mathrm{p}=0.106)$, a CFI of 0.99, a RMSEA of 0.03, a NFI of 0.94, and a GFI of 0.95 (see Table 6). The $\chi^{2}$ difference between the two models is 5.25 with $7 \mathrm{df}$ and not significant ( $\mathrm{p}$-value=0.630). Fit is not impacted by added constraints and loadings remain stable across online and mobile app samples.

In summary, results of all multi-group analyses of 9 items consistent across three contexts - store, online, and mobile app - support invariance. The PSV scale displays generalizability across these contexts. Findings confirm that consumers do experience work and/or fun in different shopping environments; however, individual items capturing the two-dimensional value structure still deviate depending on the type of environment.

\section{General discussion and conclusion}

This article corroborates the Babin et al. (1994) PSV scale in current store shopping experiences and extends the scale to online and mobile app contexts as timelier shopping environments. The study relies on 20 initial PSV items and identifies new item combinations best representing hedonic and utilitarian value in these three contexts. CFA and multi-group analyses across six different samples demonstrate reliability, validity, and stability of PSV context-specific items.

Overall findings confirm that consumers' value perceptions remain stable across different environments, but how consumers extract value has evolved over time and varies across store, online, and mobile app contexts. This shift is empirically evident in the diverging number and nature of items capturing value in the present research versus 25 years ago and is practically evident in consumer behavior today.

\subsection{Theoretical contributions}


Corroboration and extension results support the original article's research discussion positioning shopping as an experience and value as its key outcome. Shopping is still about work and/or fun in today's shopping experiences since six studies validate the two-dimensional structure of hedonic and utilitarian value for store, online, and mobile app contexts. However, different items represent hedonic and utilitarian value in these three contexts (see Table 5): 14 store items [10 hedonic value $(1-6 ; 8-10,13), 4$ utilitarian value $(14-16,18)], 14$ online items $[10$ hedonic value $(1-8 ; 10,13), 4$ utilitarian value (14-15, 17-18)], and 12 mobile app items [8 hedonic value (1-4; 6-9), 4 utilitarian value $(14-16,18)]$. Importantly, item purification excludes item modification or adaptation to allow for comparability of results across contexts. Thus, contextspecific PSV scales are neither the focus nor the result of this corroboration research.

Only nine value items are consistent across all three contexts (see Table 5). Additionally, one of these nine items is not one of the original 15 PSV scale items, yet now captures utilitarian value in all three contexts: "I feel this shopping trip was successful." The increased importance of success represented in this utilitarian value item could reflect consumers' strive for smart shopping (Green Atkins \& Kim, 2012) or efficiency and productivity in contemporary society (Anitsal \& Schumann, 2007).

To examine generalizability of scale items across contexts, multi-group CFA estimates the nine common scale items. The items display generalizability across the three contexts in support of invariance and overall measurement quality. Just as previous researchers have administered hedonic and utilitarian value in different contexts, current findings suggest that results remain comparable across shopping environments.

Fundamental theoretical contributions relate to the previously discussed unique items capturing hedonic and utilitarian value across store, online, and mobile app shopping experiences. 
For store shopping, 14 new items best represent hedonic and utilitarian shopping value. These items suggest that hedonic value still includes facets of enjoyment and excitement, yet now incorporates a new component of fantasizing previously dropped from the original PSV scale. This fantasizing item reflects changing consumer expectations towards stores in omni-channel retail environments. Since retailers strive to provide entertainment during shopping experiences, fantasizing seems to be an appropriate facet of hedonic value in contemporary retail stores (Kozinets et al., 2002).

This fantasizing element of hedonic value is evident in the 14 online items. Here, fantasizing in online experiences could be linked to flow when consumers forget their surrounding due to being completely immersed in their shopping activity (Novak et al., 2000). The current research confirms the relationship between flow and online shopping value.

For mobile app environments, the 12 items capturing value exclude facets of adventure, fantasizing, and excitement related to new products, which are included in store and online items. Flow also appears to be less important in driving value when shopping on mobile apps; especially for utilitarian value. One possible explanation could be that a majority of consumers in both studies (study 5 and study 6) utilize apps for repurchases. Thus, behavior and items may indicate that mobile app consumers engage in smart shopping and seek efficiency rather than entertainment in shopping (Anitsal \& Schumann, 2007; Green Atkins \& Kim, 2012).

\subsection{Managerial contributions}

The current research has clear implications for retailers, particularly when managing omnichannel shopping experiences consisting of multiple channel and touchpoint experiences (Verhoef et al., 2015; Huré et al., 2017). While present results confirm the importance of hedonic and utilitarian value in today's shopping experiences, variation in item quantity and content suggests 
that some elements of value may be more important in certain contexts than in others. This finding reflects contemporary consumer behavior that culminates multiple shopping experiences across channels and touchpoints to a holistic omni-channel experience (Verhoef et al., 2015).

Retailers are tasked with managing a comprehensive retail ecosystem to deliver a consistent shopping experience across intermingled channels and touch points by relying on different media tools to communicate a cohesive value-driven message. The current findings suggest that retailers must adjust the experience to the shopping contexts since perceived shopping value deviates. Nevertheless, consistency within the overall retail strategy is essential given the omni-channel shopping behavior of consumers.

For example, consumers seek experiential shopping experiences in stores and online, yet not on mobile apps. Therefore, retailers should develop less experiential shopping experiences for mobile apps than for stores and websites. Further, whereas consumers extract hedonic value from being immersed in exciting new product experiences in stores and on websites, this is not the case for mobile apps. Retailers should consequently launch new products in stores and on websites.

Results confirm the effect of individual dimensions of flow on hedonic and utilitarian value, not only for online but also for store and mobile app contexts. Thus, retailers implementing an omni-channel strategy should manage consumers' state of flow and subsequently value perceptions by aligning store, online, and mobile app strategies. Managers need to focus on certain elements of flow individually for each retail environment, since not all dimensions of flow are equally important in driving value in each context.

The current findings support Babin et al.'s (1994) acknowledgement that the original PSV scale captures store shopping experiences and that easy adaptation "to other consumption contexts is questionable" (p. 654). Beyond the original mid-1990s in-store context, researchers risk not 
measuring what the scale intends to assess (Ortinau, 2011). Therefore, researchers and practitioners should avoid blindly incorporating or adapting scales developed in specific contexts due to limited applicability - as supported by current findings.

\subsection{Limitations and future research}

As with any research, this study is subject to limitations. The scale corroboration procedure picks up at the initial scale development stage evaluating 20 items accessible in the original article due to the unavailability of the initial 71 items. Consequently, this research cannot follow the complete scale development process or identify potential additional dimensions as introduced by the original authors. For example, the latter outline the idea of informational value, which could be more applicable in online or mobile app shopping rather than store environments (Citrin, Stem, Spangenberg, \& Clark, 2003).

Another limitation involves the survey methodology and the data collection process for studies 1 and 2 as adjustments reflect common research procedures. Instead of implementing an in-person data collection approach, a panel data company collected a US online consumer sample. Nevertheless, participants report details on specific shopping experiences within the recent days consistent with the original article. Multiple qualifying questions and attention checks further ensure that only representative consumers with appropriate shopping experiences encompass the final sample.

While the current article considers two new contexts beyond store, more contexts such as TV or wearable device shopping could be of interest from an omni-channel perspective. Future research needs to look into more varied shopping experiences for a holistic approach to hedonic and utilitarian value. Findings also indicate that utilitarian value for mobile app shopping does not seem to involve shopping on multiple apps. Additional research is needed to further investigate 
how consumers utilize mobile apps to fulfill their shopping needs and identify potential differences to other shopping environments.

In conclusion, current findings echo the original authors caution to nonchalantly adapt the PSV scale to other consumption contexts due to situational fluctuations impacting consumers' hedonic and utilitarian responses across different consumption environments (Holbrook \& Hirschman, 1982). Researchers can draw on present efforts for future projects to either adapt the existing PSV scale to desired contexts following appropriate scale development procedures or develop new scales for specific consumption contexts following the original authors' advice; that is, start the process with a more encompassing list of scale items. Ultimately, we have yet to reach a definite answer to the question "Was this experience more like work or fun?" (Babin et al., 1994, p. 654). 


\section{References}

Anitsal, I., \& Schumann, D. W. (2007). Toward a conceptualization of customer productivity: The customer's perspective on transforming customer labor into customer outcomes using technology-based self-service options. Journal of Marketing Theory and Practice, 15(4), 349-363.

Attaway, J. (1989). Influence of an expanded framework of shopping motivations and inclusion of non-store retailers on the choice set formation process. Unpublished dissertation, Baton Rouge, LA: Louisiana State University.

Atulkar, S., \& Kesari, B. (2017). Satisfaction, loyalty and repatronage intentions: Role of hedonic shopping values. Journal of Retailing and Consumer Services, 39, 23-34.

Aubrey, C., \& Judge, D. (2012). Re-imagine retail: Why store innovation is key to a brand's growth in the 'new normal', digitally-connected and transparent world. Journal of Brand Strategy, 1(1), 31-39.

Babin, B. J., Borges, A., \& James, K. (2016). The role of retail price image in a multi-country context: France and the USA. Journal of Business Research, 69(3), 1074-1081.

Babin, B. J., Darden, W. R., \& Griffin, M. (1994). Work and/or fun: Measuring hedonic and utilitarian shopping value. Journal of Consumer Research, 20(4), 644-656.

Bloch, P. H., \& Bruce, G. D. (1984). Product involvement as leisure behavior. In T. C. Kinnear (Ed), Advances in Consumer Research, 11 (pp. 197-202). Provo, UT: Association for Consumer Research.

Bridges, E., \& Florsheim, R. (2008). Hedonic and utilitarian shopping goals: The online experience. Journal of Business Research, 61(4), 309-314. 
Carpenter, J. M. (2008). Consumer shopping value, satisfaction and loyalty in discount retailing. Journal of Retailing and Consumer Services, 15(5), 358-363.

Chen, W. K., Chang, D. S., \& Chen, C. C. (2017). The role of utilitarian and hedonic values on users' continued usage and purchase intention in a social commerce environment. Journal of Economics and Management, 13(2), 193-220.

Chevalier, J. A., \& Mayzlin, D. (2006). The effect of word of mouth on sales: Online book reviews. Journal of Marketing Research, 43(3), 345-354.

Churchill, G. A. (1979). A paradigm for developing better measures of marketing constructs. Journal of Marketing Research, 16(1), 64-73.

Citrin, A. V., Stem Jr, D. E., Spangenberg, E. R., \& Clark, M. J. (2003). Consumer need for tactile input: An internet retailing challenge. Journal of Business Research, 56(11), 915-922.

DeVellis, R. F. (2016). Scale development: Theory and applications. (4 $4^{\text {th }}$ ed.). Thousand Oaks, CA: Sage publications, Fourth.

Etemad-Sajadi, R., \& Ghachem, L. (2015). The impact of hedonic and utilitarian value of online avatars on e-service quality. Computers in Human Behavior, 52, 81-86.

Faber, R. J., \& O'Guinn, T. C. (1992). A clinical screener for compulsive buying. Journal of Consumer Research, 19(3), 459-469.

Flight, R. L., Rountree, M. M., \& Beatty, S. E. (2012). Feeling the urge: Affect in impulsive and compulsive buying. Journal of Marketing Theory and Practice, 20(4), 453-465.

Fornell, C., \& Larcker, D. F. (1981). Evaluating structural equation models with unobservable variables and measurement error. Journal of Marketing Research, 18(1), 39-50. 
Fulgoni, G. M. (2014). “Omni-Channel” retail insights and the consumer's path-to-purchase: How digital has transformed the way people make purchasing decisions. Journal of Advertising Research, 54(4), 377-380.

Gallarza, M. G., Gil-Saura, I., \& Holbrook, M. B. (2011). The value of value: Further excursions on the meaning and role of customer value. Journal of Consumer Behaviour, 10(4), 179191.

Garaus, M., Wagner, U., \& Kummer, C. (2015). Cognitive fit, retail shopper confusion, and shopping value: Empirical investigation. Journal of Business Research, 68(5), 1003-1011.

Gerbing, D. W., \& Anderson, J. C. (1988). An updated paradigm for scale development incorporating unidimensionality and its assessment. Journal of Marketing Research, 25(2), $186-192$.

Green Atkins, K., \& Kim, Y. K. (2012). Smart shopping: Conceptualization and measurement. International Journal of Retail \& Distribution Management, 40(5), 360-375.

Hair, J. F., Babin, B. J., \& Krey, N. (2017). Covariance-based structural equation modeling in the Journal of Advertising: Review and recommendations. Journal of Advertising, 46(1), 163177.

Hair, J. F., Black, W. C., Babin, B. J., \& Anderson, R. E. (2010). Multivariate data analysis. (7 ed.). Upper Saddle River, NJ: Pearson Prentice Hall.

Herrington, J. C. (1996). Effects of music in service environments: A field study. Journal of Services Marketing, 10(2), 26-41.

Hoch, S. J., \& Loewenstein, G. F. (1991). Time-inconsistent preferences and consumer selfcontrol. Journal of Consumer Research, 17(4), 492-507. 
Hoffman, D. L., \& Novak, T. P. (1996). Marketing in hypermedia computer-mediated environments: Conceptual foundations. Journal of Marketing, 60(3), 50-68.

Hoffman, D. L., \& Novak, T. P. (2009). Flow online: lessons learned and future prospects. Journal of Interactive Marketing, 23(1), 23-34.

Holbrook, M. B., \& Hirschman, E. C. (1982). The experiential aspects of consumption: Consumer fantasies, feelings, and fun. Journal of Consumer Research, 9(2), 132-140.

Huré, E., Picot-Coupey, K., \& Ackermann, C.-L. (2017). Understanding omni-channel shopping value: A mixed-method study. Journal of Retailing and Consumer Services, 39, 314-330.

Jones, M. A., Reynolds K. E., \& Arnold, M. J. (2006). Hedonic and utilitarian shopping value: Investigating differential effects on retail outcomes. Journal of Business Research, 59(9), 974-981.

Kerr, G., Schultz, D. E., Kitchen, P. J., Mulhern, F. J., \& Beede, P. (2015). Does traditional advertising theory apply to the digital world?: A replication analysis questions the relevance of the elaboration likelihood model. Journal of Advertising Research, 55(4), 390-400.

Kim, S. C., Yoon, D., \& Han, E. K. (2016). Antecedents of mobile app usage among smartphone users. Journal of Marketing Communications, 22(6), 653-670.

Kozinets, R. V., Sherry, J. F., DeBerry-Spence, B., Duhachek, A., Nuttavuthisit, K., \& Storm, D. (2002). Themed flagship brand stores in the new millennium: Theory, practice, prospects. Journal of Retailing, 78(1), 17-29.

Leroi-Werelds, S., Streukens, S., Brady, M. K., \& Swinnen, G. (2014). Assessing the value of commonly used methods for measuring customer value: A multi-setting empirical study. Journal of the Academy of Marketing Science, 42(4), 430-451. 
Maxham III, J. G., \& Netemeyer, R. G. (2002). Modeling customer perceptions of complaint handling over time: The effects of perceived justice on satisfaction and intent. Journal of Retailing, 78(4), 239-252.

Mehrabian, A., \& Russell, A. J (1974). An approach to environmental psychology. Cambridge, MA: MIT Press.

Mosteller, J., Donthu, N., \& Eroglu, S. (2014). The fluent online shopping experience. Journal of Business Research, 67(11), 2486-2493.

Novak, T. P., Hoffman, D. L., \& Yung, Y.F. (2000). Measuring the customer experience in online environments: A structural modeling approach. Marketing Science, 19(1), 22-42.

Ortinau, D. J. (2011). Writing and publishing important scientific articles: A reviewer's perspective. Journal of Business Research, 64(2), 150-156.

Overby, J. W., \& Lee, E.-J. (2006). The effects of utilitarian and hedonic online shopping value on consumer preference and intentions. Journal of Business Research, 59(10-11), 11601166.

Ozturk, A. B., Nusair, K., Okumus, F., \& Hua, N. (2016). The role of utilitarian and hedonic values on users' continued usage intention in a mobile hotel booking environment. International Journal of Hospitality Management, 57, 106-115.

Porter, C. E., \& Donthu, N. (2006). Using the Technology Acceptance Model to explain how attitudes determine internet usage: The role of perceived access barriers and demographics. Journal of Business Research, 59(9), 999-1007.

Rintamäki, T., Kanto, A., Kuusela, H., \& Spence, M. T. (2006). Decomposing the value of department store shopping into utilitarian, hedonic and social dimensions: Evidence from Finland. International Journal of Retail \& Distribution Management, 34(1), 6-24. 
Rook, D. W. (1987). The buying impulse. Journal of Consumer Research, 14(2), 189-199.

Sánchez-Fernández, R., \& Iniesta-Bonillo, M. Á. (2007). The concept of perceived value: A systematic review of the research. Marketing Theory, 7(4), 427-451.

Scarpi, D., Pizzi, G., \& Visentin, M. (2014). Shopping for fun or shopping to buy: Is it different online and offline? Journal of Retailing and Consumer Services, 21(3), 258-267.

Sirakaya-Turk, E., Yuksel E., \& Martin, D. (2015). The efficacy of shopping value in predicting destination loyalty. Journal of Business Research, 68(9), 1878-1885.

Stoel, L., Wickliffe, V., \& Lee, K. H. (2004). Attribute beliefs and spending as antecedents to shopping value. Journal of Business Research, 57(10), 1067-1073.

Taylor, D., \& Levin, M. (2014). Predicting mobile app usage for purchasing and informationsharing. International Journal of Retail \& Distribution Management, 42(8), 759-774.

Treadgold, A., \& Reynolds, J. (2016). Navigating the new retail landscape: A guide for business leaders. Oxford, UK: Oxford University Press.

Tsang, E. W., \& Kwan, K. M. (1999). Replication and theory development in organizational science: A critical realist perspective. Academy of Management Review, 24(4), 759-780.

Verhoef, P. C., Kannan, P. K., \& Inman, J. J. (2015). From multi-channel retailing to omnichannel retailing: Introduction to the special issue on multi-channel retailing. Journal of Retailing, 91(2), 174-181.

Wang, L. C., Baker, J., Wagner, J. A., \& Wakefield, K. (2007). Can a retail web site be social? Journal of Marketing, 71(3), 143-157.

Zhou, L., Dai, L., \& Zhang, D. (2007). Online shopping acceptance model-A critical survey of consumer factors in online shopping. Journal of Electronic Commerce Research, 8(1), 41-63. 
Tables

Table 1.

Current corroboration process overview.

\begin{tabular}{|c|c|c|c|}
\hline & & Original PSV scale & Corroboration process \\
\hline \multirow{2}{*}{$\begin{array}{l}\text { Initial scale } \\
\text { items }\end{array}$} & Method & Focus groups & \\
\hline & Sample & 5 and 8 participants from a university & \\
\hline \multirow[t]{4}{*}{$\begin{array}{l}\text { Initial scale } \\
\text { development }\end{array}$} & Method & $\begin{array}{l}\text { In-person data collection; open-ended question to describe recent } \\
\text { shopping trip; } 53 \text { shopping value items (five-point Likert scale) }\end{array}$ & $\begin{array}{l}\text { Online data collection; open-ended question to describe recent } \\
\text { shopping trip; } 20 \text { shopping value items (five-point Likert scale) }\end{array}$ \\
\hline & Sample & 125 undergraduate students at a large Midwestern University & US online panel, 171 consumers (total sample of 451 , see Appendix A) \\
\hline & $\begin{array}{l}\text { Data } \\
\text { analysis }\end{array}$ & Step 1- EFA estimating 53 items & $\begin{array}{l}\text { Step } 1 \text { - Original } 53 \text { items are unavailable, so corroboration picks up at } \\
\text { step } 2\end{array}$ \\
\hline & & $\begin{array}{l}\text { Step } 2 \text { - CFA with } 20 \text { items } \\
\text { Step } 3 \text { - Examination of convergent validity using two judges } \\
\text { ratings of shopping descriptions on a three-point scale (low, } \\
\text { average, high) regarding utilitarian and hedonic value content; } \\
\text { estimation of ANOVA models with summed factor scores }\end{array}$ & $\begin{array}{l}\text { Step } 2 \text { - CFA with } 20 \text { items } \\
\text { Step } 3 \text { - Examination of convergent validity using two judges ratings } \\
\text { of shopping descriptions on a three-point scale (low, average, high) } \\
\text { regarding utilitarian and hedonic value content; estimation of ANOVA } \\
\text { models with summed factor scores; computation of C.R. and AVEs }\end{array}$ \\
\hline \multirow[t]{4}{*}{$\begin{array}{l}\text { Scale } \\
\text { validation }\end{array}$} & Method & $\begin{array}{l}\text { Sampling approaches and measures*: } \\
\text { 1) paper-pencil survey prior to shopping trip (measures: } \\
\text { experiential shopping motivation, compulsive spending } \\
\text { tendencies, demographics) } \\
\text { 2) mall intercept interview (measures: P-A-D, bargain available } \\
\text { in store, purchase behavior, original intended purchases, total } \\
\text { amount of purchases, planned vs. unplanned purchases, time } \\
\text { pressure) }\end{array}$ & $\begin{array}{l}\text { Sampling approaches and measures*: } \\
\text { 1) online survey (original measures: shopping value items, experiential } \\
\text { shopping motivation, compulsive spending tendencies, P-A-D, bargain } \\
\text { available in store, purchase behavior, original intended purchases, total } \\
\text { amount of purchases, planned vs. unplanned purchases, time pressure, } \\
\text { satisfaction, demographics) } \\
\text { 2) online survey (contemporary measures: word of mouth, repatronage } \\
\text { intention, flow) }\end{array}$ \\
\hline & & $\begin{array}{l}\text { 3) telephone interview three days after shopping trip (measures: } \\
\text { shopping value, satisfaction) } \\
\text { *measures anchored on a five-point scale where appropriate }\end{array}$ & *measures anchored on a five-point scale where appropriate \\
\hline & Sample & 400 adult residents in a large Midwestern community & US online panel, 151 consumers (total sample of 453 , see Appendix A) \\
\hline & $\begin{array}{l}\text { Data } \\
\text { analysis }\end{array}$ & $\begin{array}{l}\text { Step } 1 \text { - CFA } \\
\text { Step } 2 \text { - Correlation analyses for nomological validity }\end{array}$ & $\begin{array}{l}\text { Step } 1 \text { - CFA } \\
\text { Step } 2 \text { - Correlation analyses for nomological validity }\end{array}$ \\
\hline
\end{tabular}


Table 2.

Corroboration studies: Overview of confirmatory factor analyses results for store condition.

\begin{tabular}{|c|c|c|c|c|c|c|c|c|c|}
\hline \multirow{4}{*}{$\begin{array}{l}\text { Study } 1 \\
\text { Study 2* }\end{array}$} & \multirow{2}{*}{\multicolumn{3}{|c|}{$\begin{array}{l}\text { Original PSV scale } \\
\text { Original } 15 \text { items }\end{array}$}} & \multicolumn{6}{|c|}{ Corroboration: Store } \\
\hline & & & & \multicolumn{3}{|c|}{ Original 15 items } & \multicolumn{3}{|c|}{ New 14 items } \\
\hline & \multicolumn{2}{|c|}{ Factor loadings } & \multirow[b]{2}{*}{$\begin{array}{l}\text { Item-total } \\
\text { correlation }\end{array}$} & \multicolumn{2}{|c|}{ Factor loadings } & \multirow[b]{2}{*}{$\begin{array}{l}\text { Item-total } \\
\text { correlation }\end{array}$} & \multicolumn{2}{|c|}{ Factor loadings } & \multirow[b]{2}{*}{$\begin{array}{l}\text { Item-total } \\
\text { correlation }\end{array}$} \\
\hline & $\mathrm{HV}$ & UV & & $\mathrm{HV}$ & UV & & $\mathrm{HV}$ & UV & \\
\hline Hedonic & & & & & & & & & \\
\hline 1. This shopping trip was truly a joy. & $\begin{array}{l}0.84 \\
\mathbf{0 . 8 1}\end{array}$ & & $\begin{array}{l}0.86 \\
\mathbf{0 . 7 8}\end{array}$ & $\begin{array}{l}0.79 \\
\mathbf{0 . 7 9}\end{array}$ & & $\begin{array}{l}0.72 \\
\mathbf{0 . 7 3}\end{array}$ & $\begin{array}{l}0.78 \\
\mathbf{0 . 8 0}\end{array}$ & & $\begin{array}{l}0.73 \\
\underline{0.74}\end{array}$ \\
\hline $\begin{array}{l}\text { 2. Compared to other things I could } \\
\text { have done, the time spent shopping } \\
\text { was truly enjoyable. }\end{array}$ & $\begin{array}{l}0.73 \\
\mathbf{0 . 8 3}\end{array}$ & & $\begin{array}{l}0.81 \\
\underline{\mathbf{0 . 8 0}}\end{array}$ & $\begin{array}{l}0.82 \\
\mathbf{0 . 7 8}\end{array}$ & & $\begin{array}{l}0.77 \\
\underline{\mathbf{0 . 7 2}}\end{array}$ & $\begin{array}{l}0.81 \\
\underline{0.77}\end{array}$ & & $\begin{array}{l}0.77 \\
\underline{\mathbf{0 . 7 2}}\end{array}$ \\
\hline $\begin{array}{l}\text { 3. During the trip, I felt the excitement } \\
\text { of the hunt. }\end{array}$ & $\begin{array}{l}0.70 \\
\underline{\mathbf{0 . 7 6}}\end{array}$ & & $\begin{array}{l}0.69 \\
\underline{\mathbf{0 . 7 4}}\end{array}$ & $\begin{array}{l}0.75 \\
\underline{0.74}\end{array}$ & & $\begin{array}{l}0.68 \\
\underline{\mathbf{0 . 6 8}} \\
\end{array}$ & $\begin{array}{l}0.76 \\
\underline{0.74}\end{array}$ & & $\begin{array}{l}0.71 \\
\underline{\mathbf{0 . 6 9}}\end{array}$ \\
\hline $\begin{array}{l}\text { 4. This shopping trip truly felt like an } \\
\text { escape. }\end{array}$ & $\begin{array}{l}0.73 \\
\underline{\mathbf{0 . 7 6}}\end{array}$ & & $\begin{array}{l}0.66 \\
\mathbf{0 . 7 6}\end{array}$ & $\begin{array}{l}0.77 \\
\mathbf{0 . 7 4}\end{array}$ & & $\begin{array}{l}0.73 \\
\underline{\mathbf{0 . 7 0}}\end{array}$ & $\begin{array}{l}0.78 \\
\mathbf{0 . 7 4}\end{array}$ & & $\begin{array}{l}0.75 \\
\underline{\mathbf{0 . 7 1}}\end{array}$ \\
\hline $\begin{array}{l}\text { 5.I enjoyed being immersed in exciting } \\
\text { new products. }\end{array}$ & $\begin{array}{l}0.66 \\
\underline{0.77}\end{array}$ & & $\begin{array}{l}0.71 \\
\mathbf{0 . 7 0}\end{array}$ & $\begin{array}{l}0.69 \\
\underline{0.71}\end{array}$ & & $\begin{array}{l}0.65 \\
\underline{0.66}\end{array}$ & $\begin{array}{l}0.69 \\
\underline{0.70}\end{array}$ & & $\begin{array}{l}0.65 \\
\underline{0.65}\end{array}$ \\
\hline $\begin{array}{l}\text { 6. I enjoyed this shopping trip for its } \\
\text { own sake, not just for the items I may } \\
\text { have purchased. }\end{array}$ & $\begin{array}{l}0.76 \\
\underline{0.71}\end{array}$ & & $\begin{array}{l}0.80 \\
\underline{\mathbf{0 . 6 8}}\end{array}$ & $\begin{array}{l}0.69 \\
\underline{0.73}\end{array}$ & & $\begin{array}{l}0.65 \\
\underline{0.68} \\
\end{array}$ & $\begin{array}{l}0.68 \\
\underline{0.71}\end{array}$ & & $\begin{array}{l}0.62 \\
\underline{0.65}\end{array}$ \\
\hline $\begin{array}{l}\text { 7. I continued to shop, not because I had } \\
\text { to, but because I wanted to. }\end{array}$ & $\begin{array}{l}0.72 \\
\underline{\mathbf{0 . 6 9}}\end{array}$ & & $\begin{array}{l}0.72 \\
\underline{\mathbf{0 . 6 7}}\end{array}$ & $\begin{array}{l}0.56 \\
\underline{\mathbf{0 . 5 9}}\end{array}$ & & $\begin{array}{l}0.55 \\
\underline{\mathbf{0 . 5 7}}\end{array}$ & & & \\
\hline $\begin{array}{l}\text { 8. I had a good time because I was able } \\
\text { to act on the "spur of the moment." }\end{array}$ & $\begin{array}{l}0.69 \\
\mathbf{0 . 6 9} \\
\end{array}$ & & $\begin{array}{l}0.66 \\
\underline{\mathbf{0 . 6 7}}\end{array}$ & $\begin{array}{l}0.68 \\
\underline{\mathbf{0 . 6 3}}\end{array}$ & & $\begin{array}{l}0.65 \\
\underline{0.61}\end{array}$ & $\begin{array}{l}0.68 \\
\underline{0.64}\end{array}$ & & $\begin{array}{l}0.65 \\
\underline{0.62}\end{array}$ \\
\hline $\begin{array}{l}\text { 9. While shopping, I was able to forget } \\
\text { my problems. }\end{array}$ & $\begin{array}{l}0.62 \\
\underline{\mathbf{0 . 7 1}}\end{array}$ & & $\begin{array}{l}0.60 \\
\underline{\mathbf{0 . 6 9}}\end{array}$ & $\begin{array}{l}0.64 \\
\underline{\mathbf{0 . 5 6}}\end{array}$ & & $\begin{array}{l}0.62 \\
\underline{\mathbf{0 . 5 4}}\end{array}$ & $\begin{array}{l}0.64 \\
\underline{0.57}\end{array}$ & & $\begin{array}{l}0.62 \\
\underline{0.56}\end{array}$ \\
\hline $\begin{array}{l}\text { 10. While shopping, I felt a sense of } \\
\text { adventure. }\end{array}$ & $\begin{array}{l}0.68 \\
\underline{\mathbf{0 . 7 3}}\end{array}$ & & $\begin{array}{l}0.76 \\
\underline{\mathbf{0 . 7 1}}\end{array}$ & $\begin{array}{l}0.78 \\
\underline{\mathbf{0 . 7 2}}\end{array}$ & & $\begin{array}{l}0.78 \\
\underline{\mathbf{0 . 7 2}}\end{array}$ & $\begin{array}{l}0.79 \\
\underline{\mathbf{0 . 7 4}}\end{array}$ & & $\begin{array}{l}0.77 \\
\underline{\mathbf{0 . 7 2}}\end{array}$ \\
\hline $\begin{array}{l}\text { 11. This shopping trip was not a very } \\
\text { nice time out. }\end{array}$ & $\begin{array}{l}-0.71 \\
\underline{\mathbf{0 . 7 2}} \\
\end{array}$ & & $\begin{array}{l}-0.75 \\
\mathbf{- 0 . 6 8}\end{array}$ & $\begin{array}{l}-0.15 \\
\mathbf{- 0 . 1 9}\end{array}$ & & $\begin{array}{l}-0.14 \\
\mathbf{- 0 . 1 8}\end{array}$ & & & \\
\hline 12.I felt really unlucky during this trip. & $\begin{array}{c}-0.63 \\
\ldots\end{array}$ & & $\begin{array}{c}-0.67 \\
\ldots\end{array}$ & & & & & & \\
\hline
\end{tabular}


13. I was able to do a lot of fantasizing during this trip.

\section{Utilitarian}

14. I accomplished just what I wanted to on this shopping trip.

15. I couldn't buy what I really needed.

16. While shopping, I found just the item(s) I was looking for.

17. I was disappointed because I had to go to another store(s) to complete my shopping.

18.I feel this shopping trip was successful.

19.I feel really smart about this shopping trip.

20. This was a good store visit because it was over very quickly.

Cronbach alpha

Fit indices

$\chi^{2}$

df

p-value

CFI

GFI

RMSR/RMSEA**

NFI

$0.57 \quad 0.54$

$\begin{array}{llll}0.77 & 0.61 & 0.83 & 0.64 \\ \underline{\mathbf{0 . 8 1}} & \underline{\mathbf{0 . 6 4}} & \underline{\mathbf{0 . 8 4}} & \underline{\mathbf{0 . 5 7}} \\ -0.64 & -0.60 & -0.57 & -0.53 \\ \underline{\mathbf{0 . 6 2}} & \underline{\mathbf{0 . 5 7}} & \underline{\mathbf{0 . 5 8}} & \underline{\mathbf{0 . 5 3}} \\ 0.74 & 0.56 & 0.75 & 0.59 \\ \underline{\mathbf{0 . 7 2}} & \underline{\mathbf{0 . 5 6}} & \underline{\mathbf{0 . 7 2}} & \underline{\mathbf{0 . 5 5}}\end{array}$


Table 3.

Correlation estimates between value factors and other variables.

\begin{tabular}{|c|c|c|c|c|c|c|c|c|c|}
\hline \multirow{3}{*}{ Scale } & \multicolumn{4}{|c|}{ Original PSV scale } & \multicolumn{5}{|c|}{ Corroboration study 2} \\
\hline & \multirow[b]{2}{*}{ \# items } & \multicolumn{3}{|c|}{ Correlation estimates } & \multirow[b]{2}{*}{ \# items } & \multirow[b]{2}{*}{ Context } & \multirow[b]{2}{*}{$\alpha$} & \multicolumn{2}{|c|}{ Correlation estimates } \\
\hline & & $\alpha$ & $\mathrm{HV}$ & UV & & & & $\mathrm{HV}$ & UV \\
\hline $\begin{array}{l}\text { Experiential shopping } \\
\text { motivations }\end{array}$ & 8 & 0.86 & $0.56^{* * *}$ & -0.02 & 9 & $\begin{array}{l}\text { Store } \\
\text { Online } \\
\text { Mobile App }\end{array}$ & $\begin{array}{l}0.86 \\
0.87 \\
0.83\end{array}$ & $\begin{array}{l}0.56 * * * \\
0.69 * * * \\
0.53 * * *\end{array}$ & $\begin{array}{l}0.04 \\
0.20^{*} \\
0.14\end{array}$ \\
\hline Compulsive buying scale & 5 & 0.76 & $0.34 * * *$ & -0.08 & 6 & $\begin{array}{l}\text { Store } \\
\text { Online } \\
\text { Mobile App }\end{array}$ & $\begin{array}{l}0.82 \\
0.81 \\
0.81\end{array}$ & $\begin{array}{l}0.09 \\
0.22 * * \\
0.10\end{array}$ & $\begin{array}{l}-0.87 \\
-0.31 * * * \\
-0.09\end{array}$ \\
\hline Pleasure & 6 & 0.85 & $0.47 * * *$ & $0.31 * * *$ & 6 & $\begin{array}{l}\text { Store } \\
\text { Online } \\
\text { Mobile App }\end{array}$ & $\begin{array}{l}0.94 \\
0.89 \\
0.92\end{array}$ & $\begin{array}{l}0.67 * * * \\
0.52 * * * \\
0.40 * * *\end{array}$ & $\begin{array}{l}0.50 * * * \\
0.27 * \\
0.16\end{array}$ \\
\hline Arousal & 5 & 0.86 & $0.61 * * *$ & $0.26^{* * *}$ & 6 & $\begin{array}{l}\text { Store } \\
\text { Online } \\
\text { Mobile App }\end{array}$ & $\begin{array}{l}0.81 \\
0.78 \\
0.82\end{array}$ & $\begin{array}{l}0.59 * * * \\
0.57 * * * \\
0.40 * * *\end{array}$ & $\begin{array}{l}0.30 * * \\
0.01 \\
0.06\end{array}$ \\
\hline Bargain perceptions & 1 & $\ldots$ & $0.29 * * *$ & $0.26^{* * *}$ & 4 & $\begin{array}{l}\text { Store } \\
\text { Online } \\
\text { Mobile App }\end{array}$ & $\begin{array}{l}0.95 \\
0.95 \\
0.96\end{array}$ & $\begin{array}{l}0.34 * * * \\
0.48 * * * \\
0.24 * *\end{array}$ & $\begin{array}{l}0.26^{* *} \\
0.11 \\
-0.03\end{array}$ \\
\hline Amount spent & 1 & $\ldots$ & $0.16^{* *}$ & $0.24 * * *$ & 1 & $\begin{array}{l}\text { Store } \\
\text { Online } \\
\text { Mobile App }\end{array}$ & $\ldots$ & $\begin{array}{l}0.10 \\
0.11 \\
0.04\end{array}$ & $\begin{array}{r}0.03 \\
-0.08 \\
-0.14\end{array}$ \\
\hline Unplanned purchases & 1 & $\ldots$ & $0.18 * * *$ & 0.09 & 1 & $\begin{array}{l}\text { Store } \\
\text { Online } \\
\text { Mobile App }\end{array}$ & $\ldots$ & $\begin{array}{l}0.10 \\
0.24 * * \\
0.28 * *\end{array}$ & $\begin{array}{l}-0.26 \\
-0.35 * * * \\
-0.10\end{array}$ \\
\hline
\end{tabular}




\begin{tabular}{|c|c|c|c|c|c|c|c|c|c|}
\hline Time pressure & 3 & 0.75 & $-0.25 * * *$ & $-0.23 * * *$ & 6 & $\begin{array}{l}\text { Store } \\
\text { Online } \\
\text { Mobile App }\end{array}$ & $\begin{array}{l}0.93 \\
0.88 \\
0.92\end{array}$ & $\begin{array}{l}-0.36^{* * *} \\
-0.24^{* *} \\
-0.08\end{array}$ & $\begin{array}{l}-0.39^{* * *} \\
-0.36^{* * *} \\
-0.41^{* * *}\end{array}$ \\
\hline Satisfaction & 1 & $\ldots$ & $0.51 * * *$ & $0.53 * * *$ & 3 & $\begin{array}{l}\text { Store } \\
\text { Online } \\
\text { Mobile App }\end{array}$ & $\begin{array}{l}0.91 \\
0.92 \\
0.86\end{array}$ & $\begin{array}{l}0.50^{* * *} \\
0.46^{* * *} \\
0.47 * * *\end{array}$ & $\begin{array}{l}0.56^{* * *} \\
0.34^{* * *} \\
0.49^{* * *}\end{array}$ \\
\hline Repatronage intention & & & & & 4 & $\begin{array}{l}\text { Store } \\
\text { Online } \\
\text { Mobile App }\end{array}$ & $\begin{array}{l}0.81 \\
0.80 \\
0.79\end{array}$ & $\begin{array}{l}0.39^{* * *} \\
0.37^{* * *} \\
0.22^{* *}\end{array}$ & $\begin{array}{l}0.30^{* * *} \\
0.12 \\
0.24^{* *}\end{array}$ \\
\hline Word-of-mouth & & & & & 3 & $\begin{array}{l}\text { Store } \\
\text { Online } \\
\text { Mobile App }\end{array}$ & $\begin{array}{l}0.94 \\
0.92 \\
0.94\end{array}$ & $\begin{array}{l}0.32 * * * \\
0.37 * * * \\
0.36 * * *\end{array}$ & $\begin{array}{l}0.43^{* * *} \\
0.19^{*} \\
0.33^{* * *}\end{array}$ \\
\hline Flow - interest & & & & & 3 & $\begin{array}{l}\text { Store } \\
\text { Online } \\
\text { Mobile App }\end{array}$ & $\begin{array}{l}0.78 \\
0.71 \\
0.70\end{array}$ & $\begin{array}{l}0.71 * * * \\
0.70^{* * *} \\
0.61 * * *\end{array}$ & $\begin{array}{l}0.26^{* *} \\
0.21^{* *} \\
0.18^{*}\end{array}$ \\
\hline Flow - curiosity & & & & & 3 & $\begin{array}{l}\text { Store } \\
\text { Online } \\
\text { Mobile App }\end{array}$ & $\begin{array}{l}0.88 \\
0.91 \\
0.85\end{array}$ & $\begin{array}{l}0.59 * * * \\
0.73 * * * \\
0.61 * * *\end{array}$ & $\begin{array}{l}0.15 \\
0.08 \\
0.04\end{array}$ \\
\hline Flow - attention & & & & & 3 & $\begin{array}{l}\text { Store } \\
\text { Online } \\
\text { Mobile App }\end{array}$ & $\begin{array}{l}0.130 \\
.64 \\
0.58\end{array}$ & $\begin{array}{l}-0.19 * * \\
0.44^{* *} \\
0.43^{* * *}\end{array}$ & $\begin{array}{l}-0.12 \\
0.25^{* *} \\
-0.03\end{array}$ \\
\hline Flow - control & & & & & 2 & $\begin{array}{l}\text { Store } \\
\text { Online } \\
\text { Mobile App }\end{array}$ & $\begin{array}{l}0.78 \\
0.77 \\
0.77\end{array}$ & $\begin{array}{l}0.40^{* * *} \\
0.45^{* * *} \\
0.19\end{array}$ & $\begin{array}{l}0.39^{* * *} \\
0.28^{* * *} \\
0.05\end{array}$ \\
\hline
\end{tabular}


Table 4.

Extension studies: Overview of confirmatory factor analyses results for online and mobile app contexts.

\begin{tabular}{|c|c|c|c|c|c|c|c|c|c|c|c|}
\hline \multirow{4}{*}{ Scale items } & \multicolumn{2}{|c|}{$\begin{array}{l}\text { Study } 3 \\
\text { Study 4* }\end{array}$} & \multicolumn{4}{|c|}{ Extension: Online } & $\begin{array}{l}\text { Study } 5 \\
\text { Study 6* }\end{array}$ & \multicolumn{3}{|c|}{ Extension: Mobile App } & tome \\
\hline & \multicolumn{3}{|c|}{ Original 15 items } & \multicolumn{3}{|c|}{ New 14 items } & \multicolumn{2}{|c|}{ Original 15 items } & \multicolumn{3}{|c|}{ New 12 items } \\
\hline & \multicolumn{2}{|c|}{ Factor loading: } & \multicolumn{4}{|c|}{ Factor loadings } & Factor loadings & \multicolumn{4}{|c|}{ Factor loadings } \\
\hline & HV & UV & $\begin{array}{l}\text { Item-total } \\
\text { correlation }\end{array}$ & HV & UV & $\begin{array}{l}\text { Item-total } \\
\text { correlation }\end{array}$ & $\mathrm{HV}$ & $\begin{array}{l}\text { Item-total } \\
\text { correlation }\end{array}$ & HV & UV & $\begin{array}{l}\text { Item-total } \\
\text { correlation }\end{array}$ \\
\hline \multicolumn{12}{|l|}{ Hedonic } \\
\hline $\begin{array}{l}\text { 1. This shopping trip was truly a } \\
\text { joy. }\end{array}$ & $\begin{array}{l}0.81 \\
\underline{\mathbf{0 . 8 3}}\end{array}$ & & $\begin{array}{l}0.75 \\
\underline{\mathbf{0 . 7 6}}\end{array}$ & $\begin{array}{l}0.81 \\
\underline{\mathbf{0 . 8 3}}\end{array}$ & & $\begin{array}{l}0.75 \\
\mathbf{0 . 7 7}\end{array}$ & $\begin{array}{l}0.78 \\
\underline{\mathbf{0 . 8 0}}\end{array}$ & $\begin{array}{l}0.73 \\
\underline{\mathbf{0 . 7 3}}\end{array}$ & $\begin{array}{l}0.79 \\
\underline{\mathbf{0 . 8 2}}\end{array}$ & & $\begin{array}{l}0.71 \\
\underline{\mathbf{0 . 7 3}}\end{array}$ \\
\hline $\begin{array}{l}\text { 2. Compared to other things I could } \\
\text { have done, the time spent } \\
\text { shopping was truly enjoyable. }\end{array}$ & $\begin{array}{l}0.77 \\
\underline{\mathbf{0 . 7 9}} \\
\end{array}$ & & $\begin{array}{l}0.73 \\
\mathbf{0 . 7 5}\end{array}$ & $\begin{array}{l}0.78 \\
\underline{\mathbf{0 . 7 9}}\end{array}$ & & $\begin{array}{l}0.74 \\
\underline{\mathbf{0 . 7 4}}\end{array}$ & $\begin{array}{l}0.77 \\
\underline{\mathbf{0 . 7 9}}\end{array}$ & $\begin{array}{l}0.72 \\
\mathbf{0 . 7 4} \\
\end{array}$ & $\begin{array}{l}0.77 \\
\mathbf{0 . 7 9} \\
\end{array}$ & & $\begin{array}{l}0.71 \\
\underline{\mathbf{0 . 7 3}}\end{array}$ \\
\hline $\begin{array}{l}\text { 3. During the trip, I felt the } \\
\text { excitement of the hunt. }\end{array}$ & $\begin{array}{l}0.78 \\
\mathbf{0 . 7 7} \\
\end{array}$ & & $\begin{array}{l}0.73 \\
\underline{\mathbf{0 . 7 3}}\end{array}$ & $\begin{array}{l}0.79 \\
\mathbf{0 . 7 7}\end{array}$ & & $\begin{array}{l}0.75 \\
\mathbf{0 . 7 3}\end{array}$ & $\begin{array}{l}0.71 \\
\underline{0.74}\end{array}$ & $\begin{array}{l}0.66 \\
\underline{0.69}\end{array}$ & $\begin{array}{l}0.69 \\
\mathbf{0 . 7 2}\end{array}$ & & $\begin{array}{l}0.63 \\
\underline{0.66}\end{array}$ \\
\hline $\begin{array}{l}\text { 4. This shopping trip truly felt like } \\
\text { an escape. }\end{array}$ & $\begin{array}{l}0.83 \\
\mathbf{0 . 8 1}\end{array}$ & & $\begin{array}{l}0.77 \\
\mathbf{0 . 7 7}\end{array}$ & $\begin{array}{l}0.82 \\
\mathbf{0 . 8 1}\end{array}$ & & $\begin{array}{l}0.77 \\
\mathbf{0 . 7 7}\end{array}$ & $\begin{array}{l}0.71 \\
\underline{0.73}\end{array}$ & $\begin{array}{l}0.65 \\
\underline{0.68}\end{array}$ & $\begin{array}{l}0.72 \\
\underline{0.74}\end{array}$ & & $\begin{array}{l}0.66 \\
\mathbf{0 . 6 9}\end{array}$ \\
\hline $\begin{array}{l}\text { 5. I enjoyed being immersed in } \\
\text { exciting new products. }\end{array}$ & $\begin{array}{l}0.71 \\
\underline{\mathbf{0 . 7 8}} \\
\end{array}$ & & $\begin{array}{l}0.67 \\
\underline{\mathbf{0 . 7 5}}\end{array}$ & $\begin{array}{l}0.72 \\
\underline{0.78}\end{array}$ & & $\begin{array}{l}0.68 \\
\mathbf{0 . 7 5}\end{array}$ & $\begin{array}{l}0.59 \\
\underline{\mathbf{0 . 6 0}}\end{array}$ & $\begin{array}{l}0.54 \\
\mathbf{0 . 5 5}\end{array}$ & & & \\
\hline $\begin{array}{l}\text { 6. I enjoyed this shopping trip for } \\
\text { its own sake, not just for the } \\
\text { items I may have purchased. }\end{array}$ & $\begin{array}{l}0.68 \\
\mathbf{0 . 7 4}\end{array}$ & & $\begin{array}{l}0.64 \\
\underline{\mathbf{0 . 7 0}}\end{array}$ & $\begin{array}{l}0.68 \\
\mathbf{0 . 7 4}\end{array}$ & & $\begin{array}{l}0.64 \\
\underline{\mathbf{0 . 6 9}}\end{array}$ & $\begin{array}{l}0.66 \\
\underline{0.69}\end{array}$ & $\begin{array}{l}0.62 \\
\underline{0.63}\end{array}$ & $\begin{array}{l}0.65 \\
\underline{\mathbf{0 . 7 0}}\end{array}$ & & $\begin{array}{l}0.59 \\
\mathbf{0 . 6 3}\end{array}$ \\
\hline $\begin{array}{l}\text { 7. I continued to shop, not because } \\
\text { I had to, but because I wanted to. }\end{array}$ & $\begin{array}{l}0.63 \\
\mathbf{0 . 6 7}\end{array}$ & & $\begin{array}{l}0.60 \\
\underline{\mathbf{0 . 6 4}} \\
\end{array}$ & $\begin{array}{l}0.63 \\
\mathbf{0 . 6 7}\end{array}$ & & $\begin{array}{l}0.59 \\
\mathbf{0 . 6 4} \\
\end{array}$ & $\begin{array}{l}0.56 \\
\mathbf{0 . 5 7}\end{array}$ & $\begin{array}{l}0.52 \\
\underline{\mathbf{0 . 5 3}}\end{array}$ & $\begin{array}{l}0.56 \\
\mathbf{0 . 5 7}\end{array}$ & & $\begin{array}{l}0.52 \\
\mathbf{0 . 5 3}\end{array}$ \\
\hline $\begin{array}{l}\text { 8. I had a good time because I was } \\
\text { able to act on the "spur of the } \\
\text { moment." }\end{array}$ & $\begin{array}{l}0.67 \\
\underline{\mathbf{0 . 6 0}}\end{array}$ & & $\begin{array}{l}0.64 \\
\mathbf{0 . 5 9}\end{array}$ & $\begin{array}{l}0.66 \\
\underline{\mathbf{0 . 6 1}}\end{array}$ & & $\begin{array}{l}0.64 \\
\mathbf{0 . 6 0}\end{array}$ & $\begin{array}{l}0.60 \\
\mathbf{0 . 5 7}\end{array}$ & $\begin{array}{l}0.56 \\
\mathbf{0 . 5 4} \\
\end{array}$ & $\begin{array}{l}0.61 \\
\underline{\mathbf{0 . 5 6}}\end{array}$ & & $\begin{array}{l}0.57 \\
\underline{\mathbf{0 . 5 3}}\end{array}$ \\
\hline $\begin{array}{l}\text { 9. While shopping, I was able to } \\
\text { forget my problems. }\end{array}$ & $\begin{array}{l}0.66 \\
\underline{0.66} \\
\end{array}$ & & $\begin{array}{l}0.63 \\
\underline{0.64}\end{array}$ & & & & $\begin{array}{l}0.62 \\
\underline{0.56}\end{array}$ & $\begin{array}{l}0.59 \\
\mathbf{0 . 5 4}\end{array}$ & $\begin{array}{l}0.59 \\
\underline{0.53}\end{array}$ & & $\begin{array}{l}0.56 \\
\underline{\mathbf{0 . 5 1}}\end{array}$ \\
\hline $\begin{array}{l}\text { 10. While shopping, I felt a sense of } \\
\text { adventure. }\end{array}$ & $\begin{array}{l}0.67 \\
\underline{0.71}\end{array}$ & & $\begin{array}{l}0.65 \\
\underline{0.68}\end{array}$ & $\begin{array}{l}0.67 \\
\underline{0.71}\end{array}$ & & $\begin{array}{l}0.67 \\
\mathbf{0 . 7 0}\end{array}$ & $\begin{array}{l}0.68 \\
\underline{0.68}\end{array}$ & $\begin{array}{l}0.67 \\
\mathbf{0 . 6 7}\end{array}$ & & & \\
\hline $\begin{array}{l}\text { 11. This shopping trip was not a very } \\
\text { nice time out. }\end{array}$ & $\begin{array}{l}-0.13 \\
\mathbf{- 0 . 2 3} \\
\end{array}$ & & $\begin{array}{l}-0.12 \\
\mathbf{- 0 . 2 1}\end{array}$ & & & & $\begin{array}{l}-0.43 \\
\mathbf{- 0 . 3 5}\end{array}$ & $\begin{array}{r}-0.39 \\
\underline{\mathbf{- 0 . 3 2}} \\
\end{array}$ & & & \\
\hline
\end{tabular}


13. I was able to do a lot of fantasizing during this trip.

Utilitarian

14. I accomplished just what I

wanted to on this shopping trip. needed.

6. While shopping, I found just the item(s) I was looking for

7.I was disappointed because I had to go to another store(s) to

18. I feel this shopping trip was successful.

19.I feel really smart about this shopping trip.

20. This was a good store visit

because it was over very quickly.

\begin{tabular}{|c|c|c|}
\hline Cronbach alpha & $\begin{array}{ll}0.89 & 0.66 \\
\underline{\mathbf{0 . 9 1}} & \mathbf{0 . 6 2} \\
\end{array}$ & $\begin{array}{l}0.91 \\
\mathbf{0 . 9 2}\end{array}$ \\
\hline \multicolumn{3}{|l|}{ Fit indices } \\
\hline$\chi^{2}$ & $\begin{array}{l}146.5 \\
217.4\end{array}$ & $\begin{array}{l}130.8 \\
\mathbf{2 0 2 . 9}\end{array}$ \\
\hline \multirow[t]{2}{*}{ df } & 89 & 76 \\
\hline & $\underline{89}$ & 76 \\
\hline \multirow[t]{2}{*}{ p-value } & 0.000 & 0.000 \\
\hline & $\underline{0.000}$ & $\underline{0.000}$ \\
\hline \multirow[t]{2}{*}{ CFI } & 0.93 & $\overline{0.94}$ \\
\hline & $\underline{0.93}$ & $\underline{0.94}$ \\
\hline \multirow[t]{2}{*}{ GFI } & $\overline{0.89}$ & $\overline{0.87}$ \\
\hline & $\underline{0.91}$ & $\underline{0.91}$ \\
\hline \multirow[t]{2}{*}{ RMSR/RMSEA** } & $\overline{0.07}$ & $\overline{0.07}$ \\
\hline & $\underline{0.07}$ & $\underline{0.07}$ \\
\hline \multirow[t]{2}{*}{ NFI } & $\overline{0.85}$ & $\overline{0.87}$ \\
\hline & 0.89 & 0.90 \\
\hline
\end{tabular}

$-0.64 \quad-0.62$

$\underline{-0.58} \quad \underline{-0.51}$

$0.81 \quad 0.65$

$\underline{0.69} \quad \underline{0.52}$

$\begin{array}{llll}\mathbf{- 0 . 5 8} & \underline{\mathbf{0 . 5 3}} & \underline{\mathbf{0 . 5 0}} & \underline{\mathbf{0 . 4 5}}\end{array}$

$\begin{array}{llll}0.76 & 0.59 & 0.79 & 0.67\end{array}$

$\begin{array}{llll}0.74 & \underline{0.55} & \underline{0.75} & \underline{0.63}\end{array}$

$-0.47 \quad-0.44$

$\underline{-0.53}-\underline{-0.50}$

Note: *Study 3 and study 5 values for original and extension models are depicted in regular font, while studv 4 and studv $\mathbf{6}$ values are bold and underlined. $* *$ The original model measures root-mean-squared residual (RMSR) whereas extension models assess root mean square error of approximation (RMSEA). 
Table 5.

Hedonic and utilitarian value scale items by context.

\begin{tabular}{|c|c|c|c|c|}
\hline \multirow{2}{*}{$\begin{array}{l}\text { Scale items } \\
\text { (Babin et al., 1994) }\end{array}$} & $\begin{array}{l}\text { Original } \\
\text { PSV scale }\end{array}$ & Store & Online & $\begin{array}{l}\text { Mobile } \\
\text { App }\end{array}$ \\
\hline & 15 items & 14 items & 14 items & 12 items \\
\hline \multicolumn{5}{|l|}{ Hedonic } \\
\hline 1. This shopping trip was truly a joy. & $\checkmark$ & $\checkmark$ & $\underline{\checkmark}$ & $\checkmark$ \\
\hline $\begin{array}{l}\text { 2. Compared to other things I could have done, the time spent } \\
\text { shopping was truly enjoyable }\end{array}$ & $\checkmark$ & $\checkmark$ & $\underline{\downarrow}$ & $\checkmark$ \\
\hline 3. During the trip, I felt the excitement of the hunt. & $\checkmark$ & $\checkmark$ & $\underline{v}$ & $\checkmark$ \\
\hline 4. This shopping trip truly felt like an escape. & $\checkmark$ & $\checkmark$ & $\underline{\vee}$ & $\checkmark$ \\
\hline 5. I enjoyed being immersed in exciting new products. & $\checkmark$ & $\checkmark$ & $\underline{v}$ & - \\
\hline $\begin{array}{l}\text { 6. I enjoyed this shopping trip for its own sake, not just for } \\
\text { the items I may have purchased. }\end{array}$ & $\checkmark$ & $\checkmark$ & $\underline{\checkmark}$ & $\checkmark$ \\
\hline $\begin{array}{l}\text { 7. I continued to shop, not because I had to, but because I } \\
\text { wanted to. }\end{array}$ & $\checkmark$ & - & $\underline{v}$ & $\checkmark$ \\
\hline $\begin{array}{l}\text { 8. I had a good time because I was able to act on the "spur of } \\
\text { the moment." }\end{array}$ & $\checkmark$ & $\checkmark$ & $\underline{v}$ & $\checkmark$ \\
\hline 9. While shopping, I was able to forget my problems. & $\checkmark$ & $\checkmark$ & - & $\checkmark$ \\
\hline 10. While shopping, I felt a sense of adventure. & $\checkmark$ & $\checkmark$ & $\underline{\checkmark}$ & - \\
\hline 11. This shopping trip was not a very nice time out. & $\checkmark$ & - & - & - \\
\hline 12. I felt really unlucky during this trip. & - & - & - & - \\
\hline 13. I was able to do a lot of fantasizing during this trip. & - & $\checkmark$ & $\underline{\vee}$ & - \\
\hline \multicolumn{5}{|l|}{ Utilitarian } \\
\hline $\begin{array}{l}\text { 14. I accomplished just what I wanted to on this shopping } \\
\text { trip. }\end{array}$ & $\checkmark$ & $\checkmark$ & $\underline{v}$ & $\checkmark$ \\
\hline 15. I couldn't buy what I really needed. & $\checkmark$ & $\checkmark$ & $\underline{\vee}$ & $\checkmark$ \\
\hline 16. While shopping, I found just the item(s) I was looking for. & $\checkmark$ & $\checkmark$ & - & $\checkmark$ \\
\hline $\begin{array}{l}\text { 17. I was disappointed because I had to go to another store(s) } \\
\text { to complete my shopping. }\end{array}$ & $\checkmark$ & - & $\underline{v}$ & - \\
\hline 18. I feel this shopping trip was successful. & - & $\checkmark$ & $\underline{v}$ & $\checkmark$ \\
\hline 19. I feel really smart about this shopping trip. & - & - & - & - \\
\hline $\begin{array}{l}\text { 20. This was a good store visit because it was over very } \\
\text { quickly. }\end{array}$ & - & - & - & - \\
\hline
\end{tabular}


Table 6.

Fit indices for multi-group analysis for 9 PSV items.

\begin{tabular}{lccccccc}
\hline Model & $\chi^{2}$ & df & CFI & RMSEA & $\Delta \chi^{2}$ & df & p-value \\
\hline Store-online CFA TF & 84.30 & 52 & 0.97 & 0.05 & & & \\
Store-online CFA $\Lambda$ invariant & 88.48 & 58 & 0.97 & 0.04 & 4.18 & 7 & 0.759 \\
Store-mobile app CFA TF & 78.38 & 52 & 0.97 & 0.04 & & & \\
Store-mobile app CFA $\Lambda$ invariant & 86.02 & 59 & 0.97 & 0.04 & 7.64 & 7 & 0.366 \\
Online-mobile app CFA TF & 67.61 & 52 & 0.99 & 0.03 & & & \\
Online-mobile app CFA $\Lambda$ invariant & 72.86 & 59 & 0.99 & 0.03 & 5.25 & 7 & 0.630 \\
\hline
\end{tabular}


Appendix A. Sample descriptives

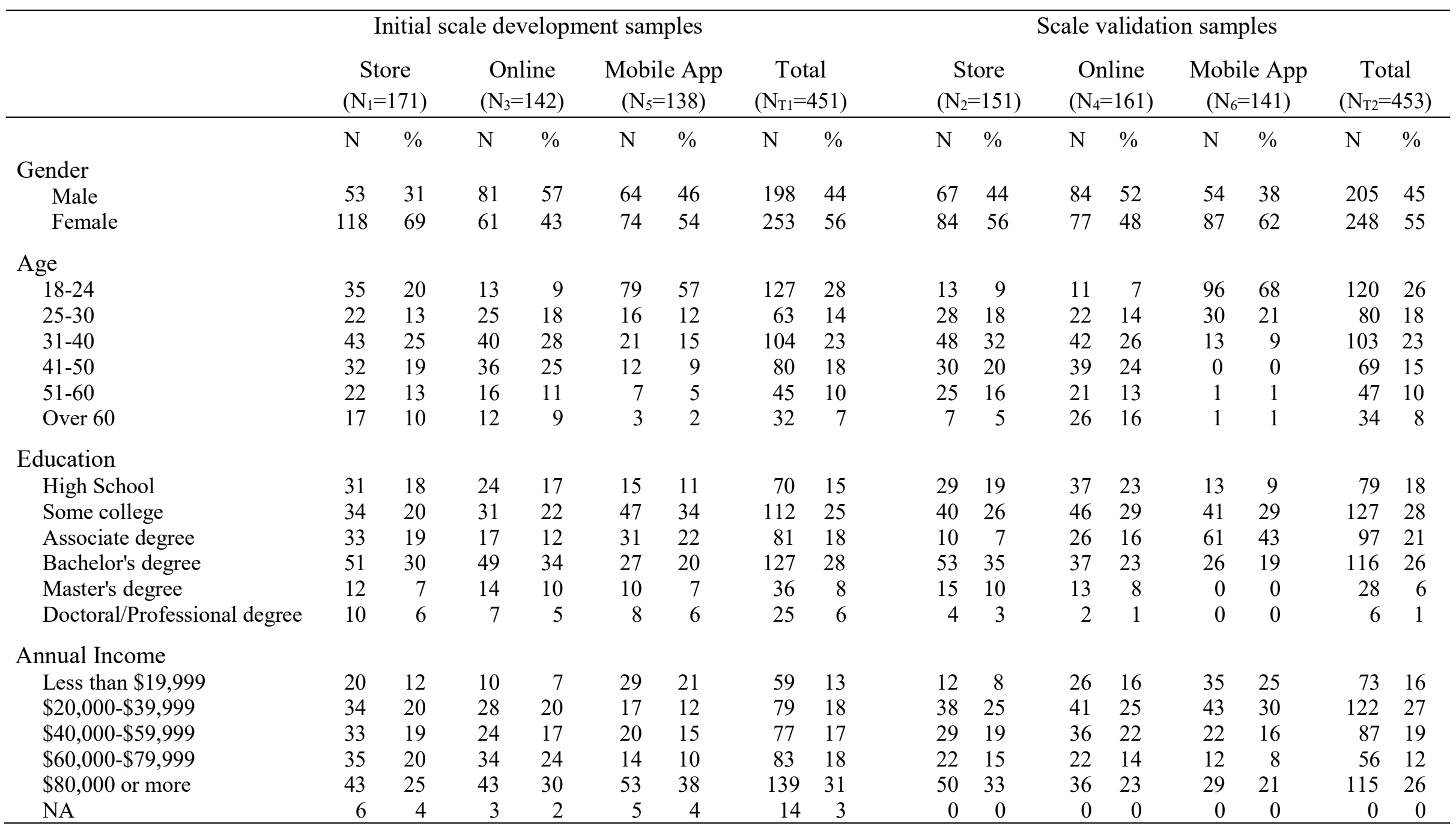

